Article

\title{
Identification and Evolution of TGF- $\beta$ Signaling Pathway Members in Twenty-Four Animal Species and Expression in Tilapia
}

\author{
Shuqing Zheng ${ }^{\dagger}$, Juan Long ${ }^{\dagger}$, Zhilong Liu, Wenjing Tao and Deshou Wang * \\ Key Laboratory of Freshwater Fish Reproduction and Development (Ministry of Education), Key Laboratory of \\ Aquatic Science of Chongqing, School of Life Sciences, Southwest University, Chongqing 400715, China; \\ zhengsq0825@163.com (S.Z.); 18883398791@163.com (J.L.); bioliu545@163.com (Z.L.); enderwin@163.com (W.T.) \\ * Correspondence: wdeshou@swu.edu.cn; Tel.: +86-23-6825-3702 \\ + These authors contributed equally to this work.
}

Received: 9 February 2018; Accepted: 4 April 2018; Published: 11 April 2018

\begin{abstract}
Transforming growth factor $\beta$ (TGF- $\beta$ ) signaling controls diverse cellular processes during embryogenesis as well as in mature tissues of multicellular animals. Here we carried out a comprehensive analysis of TGF- $\beta$ pathway members in 24 representative animal species. The appearance of the TGF- $\beta$ pathway was intrinsically linked to the emergence of metazoan. The total number of TGF- $\beta$ ligands, receptors, and smads changed slightly in all invertebrates and jawless vertebrates analyzed. In contrast, expansion of the pathway members, especially ligands, was observed in jawed vertebrates most likely due to the second round of whole genome duplication $(2 \mathrm{R})$ and additional rounds in teleosts. Duplications of TGFB2, TGFBR2, ACVR1, SMAD4 and SMAD6, which were resulted from $2 \mathrm{R}$, were first isolated. Type II receptors may be originated from the ACVR2-like ancestor. Interestingly, AMHR2 was not identified in Chimaeriformes and Cypriniformes even though they had the ligand $A M H$. Based on transcriptome data, TGF- $\beta$ ligands exhibited a tissue-specific expression especially in the heart and gonads. However, most receptors and smads were expressed in multiple tissues indicating they were shared by different ligands. Spatial and temporal expression profiles of 8 genes in gonads of different developmental stages provided a fundamental clue for understanding their important roles in sex determination and reproduction. Taken together, our findings provided a global insight into the phylogeny and expression patterns of the TGF- $\beta$ pathway genes, and hence contribute to the greater understanding of their biological roles in the organism especially in teleosts.
\end{abstract}

Keywords: transforming growth factor $\beta$ signaling pathway; evolution; teleosts; tissue distribution; gonadal expression profile

\section{Introduction}

The evolution of animals was accompanied by an increase in systematic complexity including highly specialized tissues and organs. Gene duplication has been suggested to be a primary mechanism for the increase of organismal complexity and the generation of evolutionary novelty [1]. Whole genome duplication (WGD) is one of the important mechanisms which can rapidly generate duplicate copies of genes in species evolution [2]. Many families of genes such as nuclear receptors (NRs), Wnt-protein ligands and GPCRs are known to have evolved through WGDs [3,4]. Despite being controversial, it is widely accepted that three rounds of WGD occurred during vertebrate evolution. The first two rounds of duplication events ( $1 R$ and $2 R$ ) occurred early in the vertebrate lineage, while the third event (3R) only occurred in teleosts [5-8]. Some teleosts, such as rainbow trout and common carp $[9,10]$, even have undergone the fourth round of genome duplication (4R) 
(Figure 1). After duplication, divergence both in expression patterns and protein sequences (namely subfunctionalization and neofunctionalization) can be responsible for the retention of gene duplicates [11,12]. However, massive gene loss typically followed WGDs, and in most cases only a single copy of the duplicated genes will be retained [13]. Thus, it is hard to interpret molecular phylogenies due to gene loss among distantly related lineages.

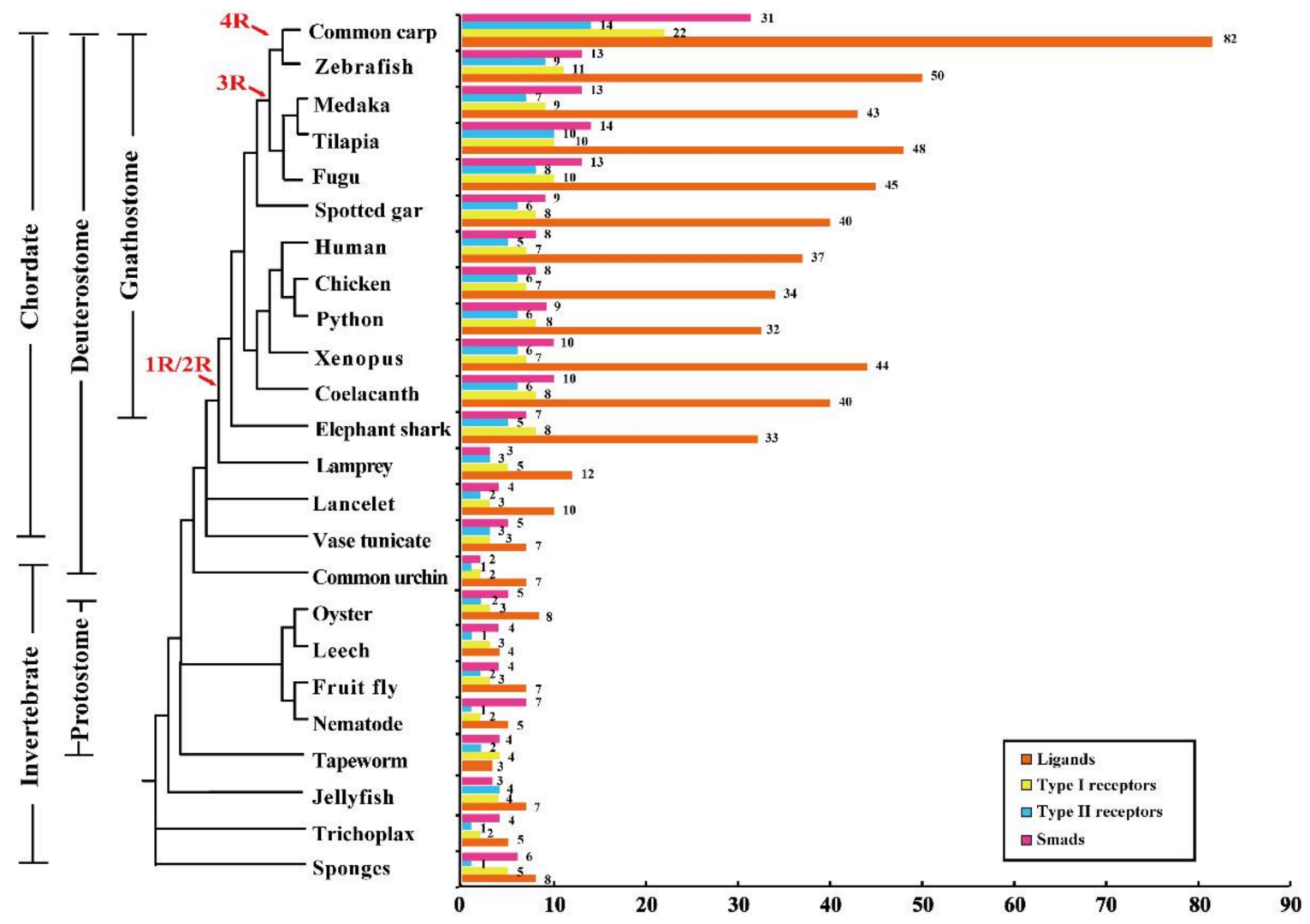

Figure 1. Phylogenetic relationship of 24 representative animals analyzed and numbers of transforming growth factor $\beta$ (TGF- $\beta$ ) pathway gene. $1 R, 2 R, 3 R$ and $4 R$ indicate the four rounds of WGD that occurred during vertebrate evolution. The complete TGF- $\beta$ pathway was first appeared in sponges, and the pathway members are universally present in all metazoans.

The transforming growth factor $\beta$ (TGF- $\beta$ ) signaling pathway consists of extracellular ligands (including TGF- $\beta$-like group and BMP-like group), cell surface receptors (including type I and type II serine-threonine kinase receptors), and intracellular smad proteins (including receptor-regulated smad (R-SMAD), common-smad (Co-SMAD), and inhibitory smad (I-SMAD)) [14,15]. TGF- $\beta$ ligands comprise a secretion signal peptide, a $\sim 250$-residue prodomain, and a $\sim 110$-residue growth factor domain which encompasses 6-9, and usually 7, conserved cysteines. 6 of the characteristic cysteine residues form 3 intramolecular disulfide bonds, and the seventh cysteine forms a intermolecular disulfide bond linking two monomers into a dimer $[16,17]$. This dimer binds to specific tetrameric type II/type I kinase receptor complexes, which stabilizes and activates type I receptors. The activated type I receptors then transduce the signals by phosphorylating the R-SMADs. In general, TGF- $\beta$-like group generally phosphorylate SMAD2 and SMAD3, whereas BMP-like group generally induce phosphorylation of SMAD1, SMAD5 and SAMD8 $[18,19]$. The activated R-SMADs form hetero-oligomeric complexes with Co-SMAD (SMAD4), which are translocated to the nucleus where they regulate the expression of target genes. I-SMADs (SMAD6 and SMAD7) can inhibit R-SMAD activation by type I receptors. 
The TGF- $\beta$ pathway members are conserved in organisms ranging from Nematoda and Arthropoda to Mammalia [20]. As for ligands, there are 9 genes in Mnemiopsis leidyi [21], 7 in Drosophila melanogaster [22], 5 in Caenorhabditis elegans [23], and at least 30 in mammals [17,24]. Two functional classes of receptors, type I and type II, which are encoded by 7 (ALK1-ACVRL1, ALK2-ACVR1, ALK3-BMPR1A, ALK4-ACVR1B, ALK5-TGFBR1, ALK6-BMPR1B, ALK7-ACVR1C) and 5 (BMPR2, ACVR2A, ACVR2B, AMHR2, and TGFBR2) genes in mammals, respectively [25,26]. Drosophila species contain three type I and two type II receptors. Extensive research on the repertoires of smads has been reported in zebrafish (12), medaka (12), fugu (13) and the green spotted puffer (14) [27]. However, to date, the origin and evolution of whole TGF- $\beta$ pathway members in the animal kingdom are still unclear because of scant analysis of this pathway in representative animal species due to lack of genome data. Recently, genomes of representative species have been sequenced and opened, such as sea lamprey (a jawless cyclostomata) [28], elephant shark (a chondrichthyan) [29], coelacanth (an early sarcopterygian) [30], spotted gar (a non-teleost actinopterygian) [31] and many teleosts. The completion of genome sequencing of these species provides new resources for tracing the evolution of this pathway.

TGF- $\beta$ pathway members create the networks that establish multicellular animal body plans. They specify anteroposterior, dorsoventral (bilateral), left-right axes, details of individual organs and regulate development and homeostasis [32-36]. The influence of the TGF- $\beta$ pathway members on fertility and reproduction in organisms as diverse as flies and humans is impressive [37]. Additionally, several recent studies have suggested that TGF- $\beta$ pathway members were involved in sex determination in fishes. These included $g s d f$ [38-41], bmp15 [42], amhr2 [43] and Y-linked duplicates of the amh (amhy) [44,45], $g s d f\left(g s d f^{Y}\right)[46]$ and $g d f 6\left(g d f 6^{Y}\right)$ [47].

However, to date, analyses of this pathway have so far been restricted to ligands, receptors or smads alone in one or several species. Expression data are available only for single or a subfamily of the TGF- $\beta$ in a particular tissue or at a single stage of development $[48,49]$. The expression profiles of most of the TGF- $\beta$ pathway genes in multiple tissues are still lacking. Moreover, other than studies in human and model organisms, little is known about the evolution and expression of TGF- $\beta$ pathway members in other species, especially in teleosts. To address these issues, we isolated TGF- $\beta$ pathway members from 24 representative animal species, performed phylogenetic analyses of the ligands, receptors and smads, and analyzed the spatial-temporal gene expression profiles in different tissues especially gonads of a teleost, the Nile tilapia.

\section{Results}

\subsection{TGF- $\beta$ Pathway Genes across Different Animals}

Comparative analyses of the TGF- $\beta$ pathway genes in 24 representative animal species revealed that the complete functional TGF- $\beta$ pathway, including multiple ligands, receptors and smads, appeared in the sponge Amphimedon queenslandica, an early diverging metazoan (Figure 1 and Table S1). In invertebrates and jawless vertebrates, the total number of TGF- $\beta$ ligands, receptors and smads changed slightly. Jawed vertebrates (gnathostomes) had an expanded set of ligands, receptors and smads most likely due to $2 \mathrm{R}$ event. Duplications of TGF- $\beta$ members were also observed from $3 R$ in teleosts and $4 \mathrm{R}$ in common carp although many TGF- $\beta$ pathway members were lost after duplication. Additionally, the number of TGF- $\beta$ ligands greatly exceeded the number of two type receptors and smads in jawed vertebrates. The accession numbers of all TGF- $\beta$ pathway members we analyzed are listed in Table S2. Genomic distribution of TGF- $\beta$ pathway members in tilapia was shown in Figure S1.

TGF- $\beta$ ligands were clustered into TGF- $\beta$-like and BMP-like clades from phylogenetic tree we generated based on mature TGF- $\beta$ peptide domains. Each clade can be subdivided into many different small groups (Figure 2). There are about 43-50 ligands in teleosts, of which 11 genes (TGFB1, TGFB3, $B M P 2, B M P 7, B M P 10, G D F 6, G D F 8, G D F 10, I N H B A$, INHBB and GDNF) marked with red dots retained two copies in teleosts which were originated from 3R. Additionally, there were 5 genes (NDR1, BMP8, $A D M P, T G F B 2$ and NRTN) which had two copies in some $2 \mathrm{R}$ species. For instance, duplication 
of TGFB2 was found for the first time in the elephant shark, coelacanth, and python (Figure S2a). Additionally, $B M P 16$, a relative of $B M P 2 / 4$, was first identified in whale shark in this study (Figure S2b).

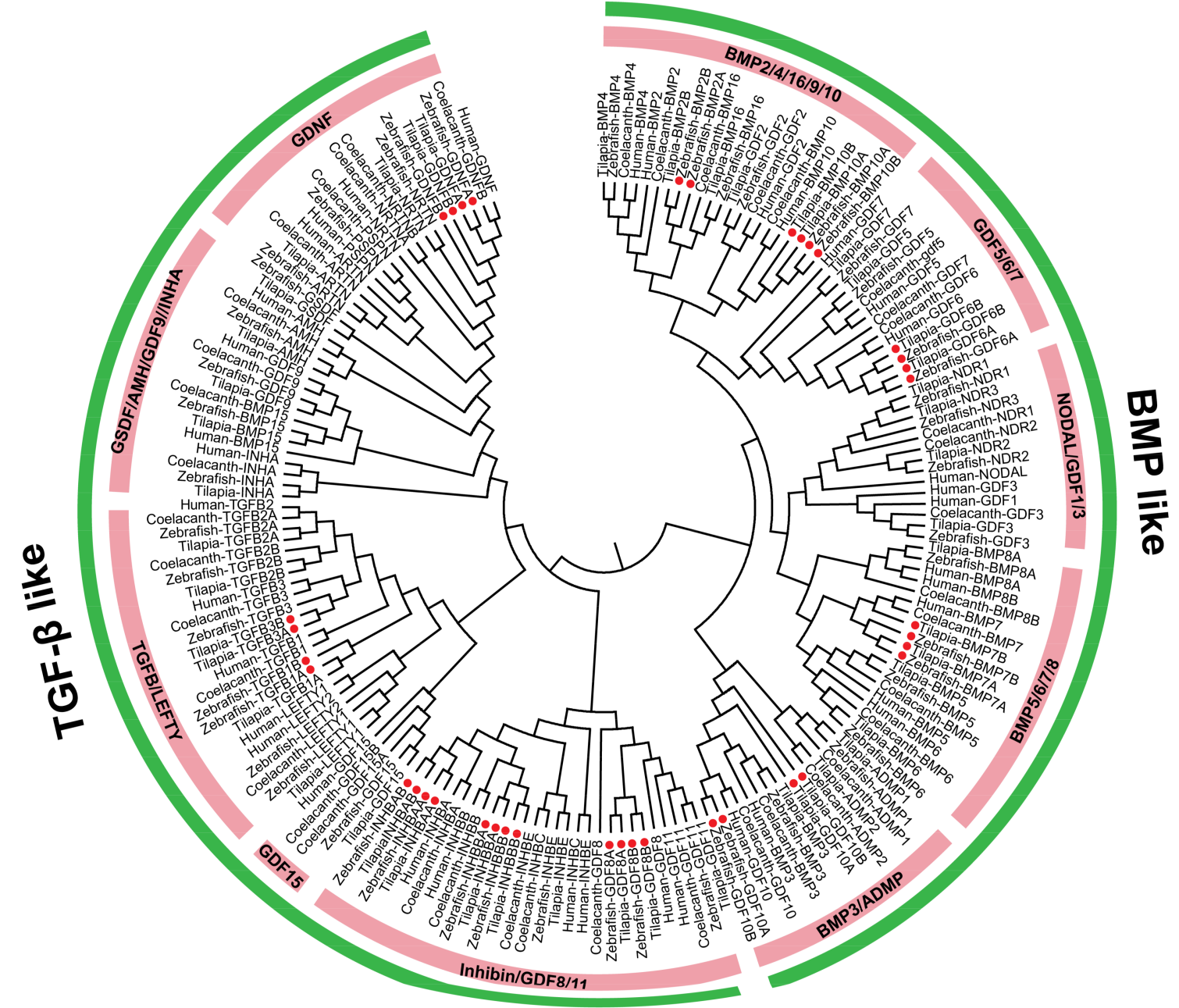

Figure 2. Phylogenetic tree of TGF- $\beta$ ligands from tilapia, zebrafish, coelacanth, and human. The TGF- $\beta$ ligands were clustered into TGF- $\beta$-like and BMP-like clades, with each clade can be subdivided into many different small groups. The ML method was used to construct the tree by MEGA 6.0 software. The amino acid sequences of TGF- $\beta$ peptide domains were aligned using the multiple alignment software Bioedit. Red dots indicate genes which retained two copies in teleosts after 3R events. GenBank accession numbers of the sequences used are listed in Table S2a.

TGF- $\beta$ type I receptors can be divided into ALK1/2, ALK3/6 and ALK4/5/7 subfamilies (Figure 3a). In teleosts, we isolated 9-11 potential type I receptors. ALK3/4/5/6 had two copies in teleosts, while only one in tetrapods. Moreover, $A C V R 1 L$, a copy gene of $A L K 2$, was isolated in the shark, coelacanth, and spotted gar in this study. Type II receptors can be divided into TGFBR2, ACVR2A/ACVR2B and BMPR2/AMHR2 subfamilies (Figure 3b). In teleosts, we identified 7-10 type II receptors. All orthologous genes of mammals have two copies in teleosts except AMHR2. In addition, AMHR2 was not found in Chimaeriformes (elephant shark, whale shark) and Cypriniformes, at least in Cyprinidae (zebrafish, common carp, grass carp and bluntnose black bream) genomes which had the corresponding ligand $A M H$ (Figure S3). In addition, duplication of TGFBR2 (TGFBR2B) was found not only in teleosts but also in birds, amphibians, reptiles, cartilage, and bony fishes. 
a

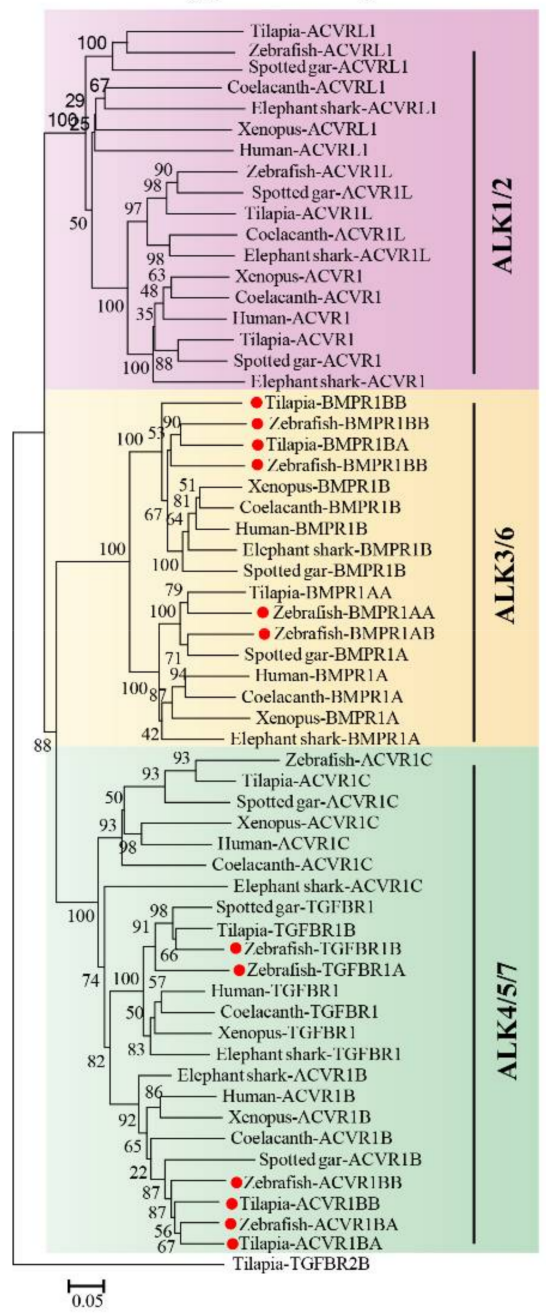

b Type II receptors

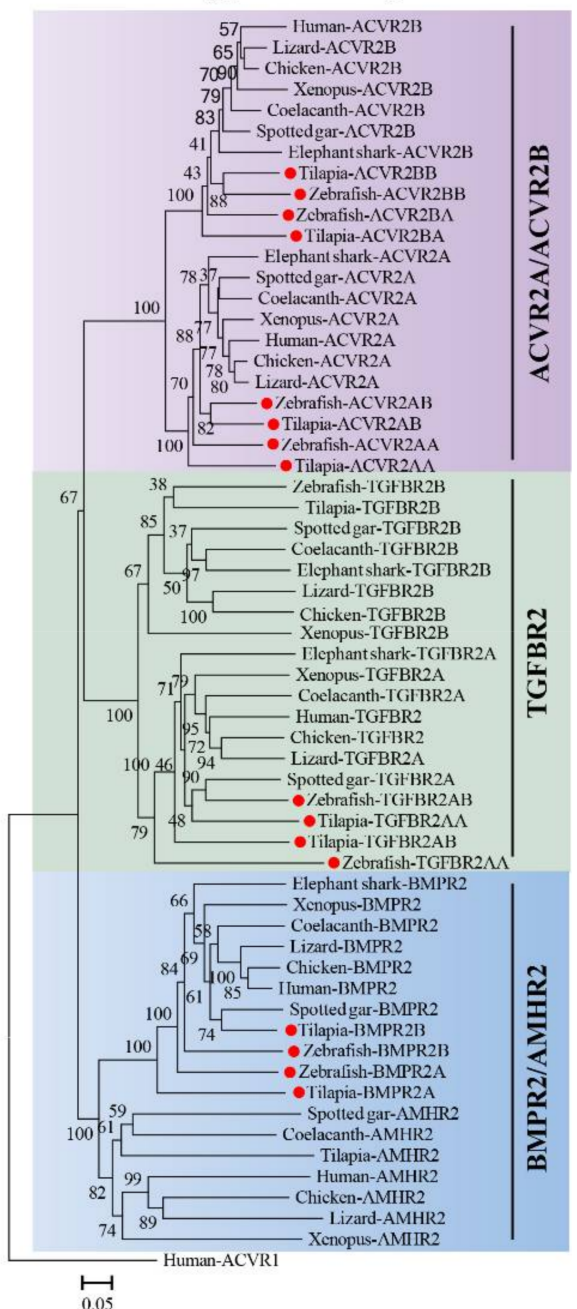

Figure 3. Phylogenetic trees of TGF- $\beta$ type I (a) and type II (b) receptors. The trees were constructed using the same method as described in Figure 2. (a) Type I receptors from elephant shark, coelacanth, spotted gar, xenopus, human, zebrafish and tilapia were clustered into ALK1/2, ALK3/6 and ALK4/5/7 three branches, tilapia TGFBR2B was used as an outgroup; (b) Type II receptors from elephant shark, coelacanth, spotted gar, xenopus, lizard, chicken, human, zebrafish and tilapia were clustered into ACVR2A/ACVR2B, TGFBR2 and BMPR2/AMHR2 three branches, human ACVR1 was used as an outgroup. Red dots indicate genes which retained two copies in teleosts after 3R events. GenBank accession numbers of the sequences used are listed in Table S2b,c.

In teleosts, smads were clustered into 3 subfamilies with 6-7 R-SMADs, 3-4 Co-SMADs and 3 I-SMADs (Figure 4). Duplications of $S M A D 2 / 3$ derived from 3R event, while $S M A D 1 / 5 / 7 / 8$ had only one copy in all species analyzed except xenopus in which two SMAD8 were identified. Phylogeny analysis of SMAD4 indicated that it has undergone 2R event to form 2 copies in coelacanth, spotted gar and xenopus, and have 4 in teleosts derived from 3R (Figure S2c). To further elucidate the SMAD4 evolutionary history, we characterized and compared the adjacent genomic regions of each SMAD4 paralogous gene loci in representative vertebrate species including tetrapods (human, chicken, lizard, and xenopus), sarcopterygians (coelacanth) and actinopterygians (spotted gar, tilapia, zebrafish, medaka, fugu, stickleback, platyfish and tetraodon) (Figure 5). Synteny analysis indicated that two $S M A D 4$, namely $S M A D 4 A$ and $S M A D 4 B$, were conserved in coelacanth, spotted gar and xenopus. Human and lizard retained $S M A D 4 A$, while chicken retained $S M A D 4 B$. The genomic regions 
of $S M A D 4 A$ and $S M A D 4 B$ have been duplicated in teleosts, likely due to the teleost $3 R$. Conserved synteny of 3R-duplicated genes in this region include MEX3C and SNAPIN. Furthermore, duplication of SMAD6 (SMAD6B) was found in coelacanth, xenopus, python, and gecko. SMAD6B in these species were clustered together but branched from SMAD6A of the vertebrates (Figure S2d).

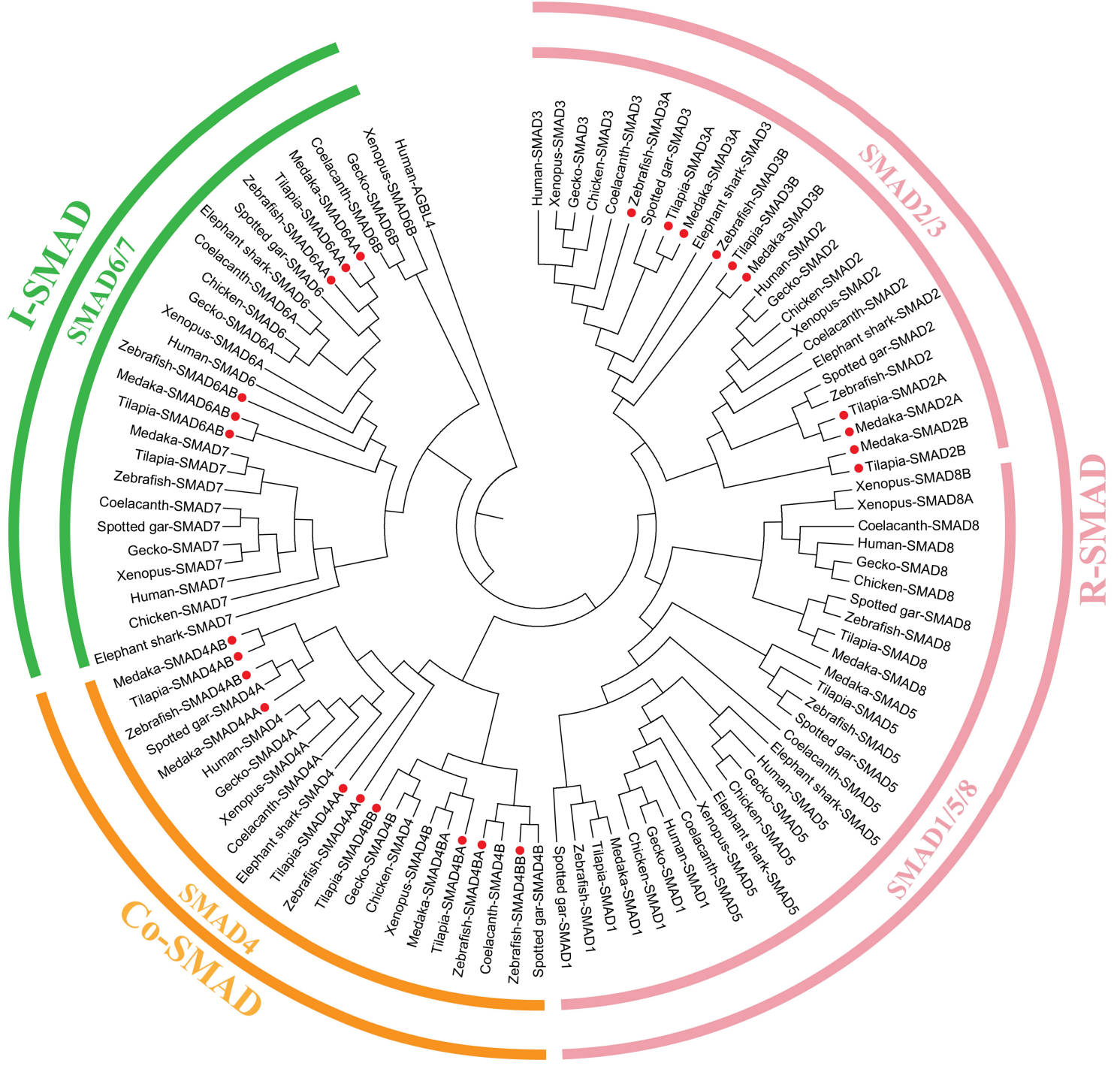

Figure 4. Phylogenetic tree of smads. The tree was constructed using the same method as described in Figure 2. Smads from elephant shark, coelacanth, spotted gar, xenopus, gecko, chicken, human, zebrafish, and tilapia were clustered into R-SMAD (SMAD1/5/8, SMAD2/3), Co-SMAD (SMAD4) and I-SMAD (SMAD6/7) branches, human AGBL4 was used as an outgroup. Red dots indicate genes which retained two copies in teleosts after 3R events. GenBank accession numbers of the sequences used are listed in Table S2d.

\subsection{Tissue Distribution and Temporal Expression of TGF- $\beta$ Pathway Members in the Tilapia Gonads}

A hierarchical cluster analysis based on transcriptome data of 8 adult tissues indicated that of the 80 identified TGF- $\beta$ superfamily members in tilapia, 25 were expressed at background level in all 8 tissues according to the threshold we set. Most of smads and two types of receptors were expressed in multiple tissues, while TGF- $\beta$ ligands exhibited a tissue-specific expression pattern with 8 ligands in the heart, 5 in the ovary, 4 in the testis and 3 in the liver (Figure 6). 

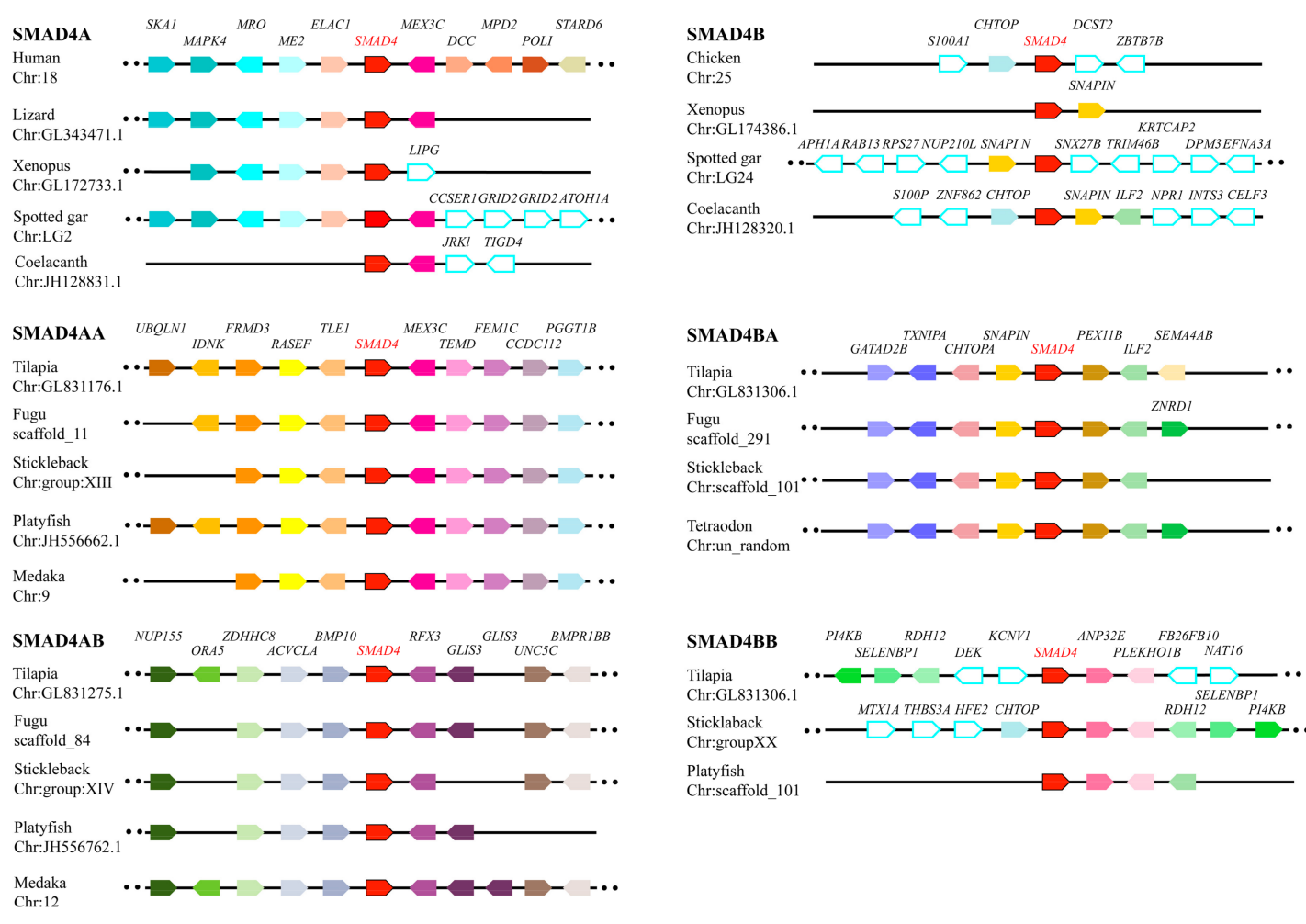

Figure 5. Syntenic analysis of SMAD4 genomic region. Genomic regions flanking SMAD4 copies were analyzed in representative vertebrate species including tetrapods (human, chicken, lizard, and xenopus), sarcopterygians (coelacanth) and actinopterygians (spotted gar, tilapia, fugu, stickleback, medaka, platyfish, and tetraodon) using Genomicus browser. The chromosome or scaffold number was indicated under the species name. The bar lengths were not proportional to the distances between genes. Dotted lines indicated omitted genes in the chromosome or scaffold. Different genes were represented by different colored pentagons and SMAD4 copies were indicated in red. The direction of pentagons indicated the gene direction. The gene names were placed on top of the pentagons.

Based on transcriptome data, 13 genes highly expressed in gonads were selected for analysis of their temporal expression patterns at different developmental stages (Figure 7). The expression levels of 9 ovary-enriched genes (admp2, bmp7a, gdf9, bmp15, gdf3, acvr2ba, smad1, smad5, smad8) were found to peak at 180 dah (days after hatching), followed by 90 and 300 dah, always higher in XX than XY gonads, while at relatively low level at early stages of gonad development $(5,7,20,30$ and 40 dah) with little difference between XX and XY gonads. Expression of 4 testis-enriched genes (inha, gsdf, amh and $a m h r 2$ ) was gradually elevated from 5 dah, significantly elevated from 20 dah and peaked at 30 dah. At the later stages, their expression levels were gradually decreased.

\subsection{Validation of Expression Profile of TGF- $\beta$ Pathway Members by qPCR and Cellular Location by In Situ Hybridization (ISH) and Immunohistochemistry (IHC)}

To verify the accuracy of transcriptome data, two genes were selected for qPCR validation of their expression. Additionally, ISH and IHC were performed for several highly expressed genes to detect their cellular location in gonads. Consistently, by qPCR, the expression levels of bmp15 and $g d f 9$ were gradually elevated during gonadal development with much higher expression in $X X$ than XY gonads at all stages (Figure S4). By ISH, strong signals (brown) of bmp15, gdf9, gdf3, smad1, smad5 and smad 8 were observed in the cytoplasm of oocytes in the ovary (Figure $8 \mathrm{a}, \mathrm{c}, \mathrm{e}, \mathrm{g}, \mathrm{i}, \mathrm{k}$ ), while no signal of these genes was observed in any cells of the testis (Figure $8 b, d, f, h, j, 1)$. Slides did not show a positive signal in the negative controls of all genes hybridized with sense probes (Figure S5). By IHC, Gsdf-specific immunostaining was clearly observed in the somatic cells neighboring oogonia of the 
XX gonads and Sertoli cells neighboring spermatogonia of the XY gonads at 5, 30, 90 and 180 dah (Figure 9a-h). The Amh proteins were located in granulosa cells in the ovary at all stages and somatic cells surrounding germ cells in the testis at 5 dah, and later stages in myoid cells and Sertoli cells (Figure 9i-p). Negative controls with the primary antibody replaced with normal rabbit serum were shown in Figure S6.

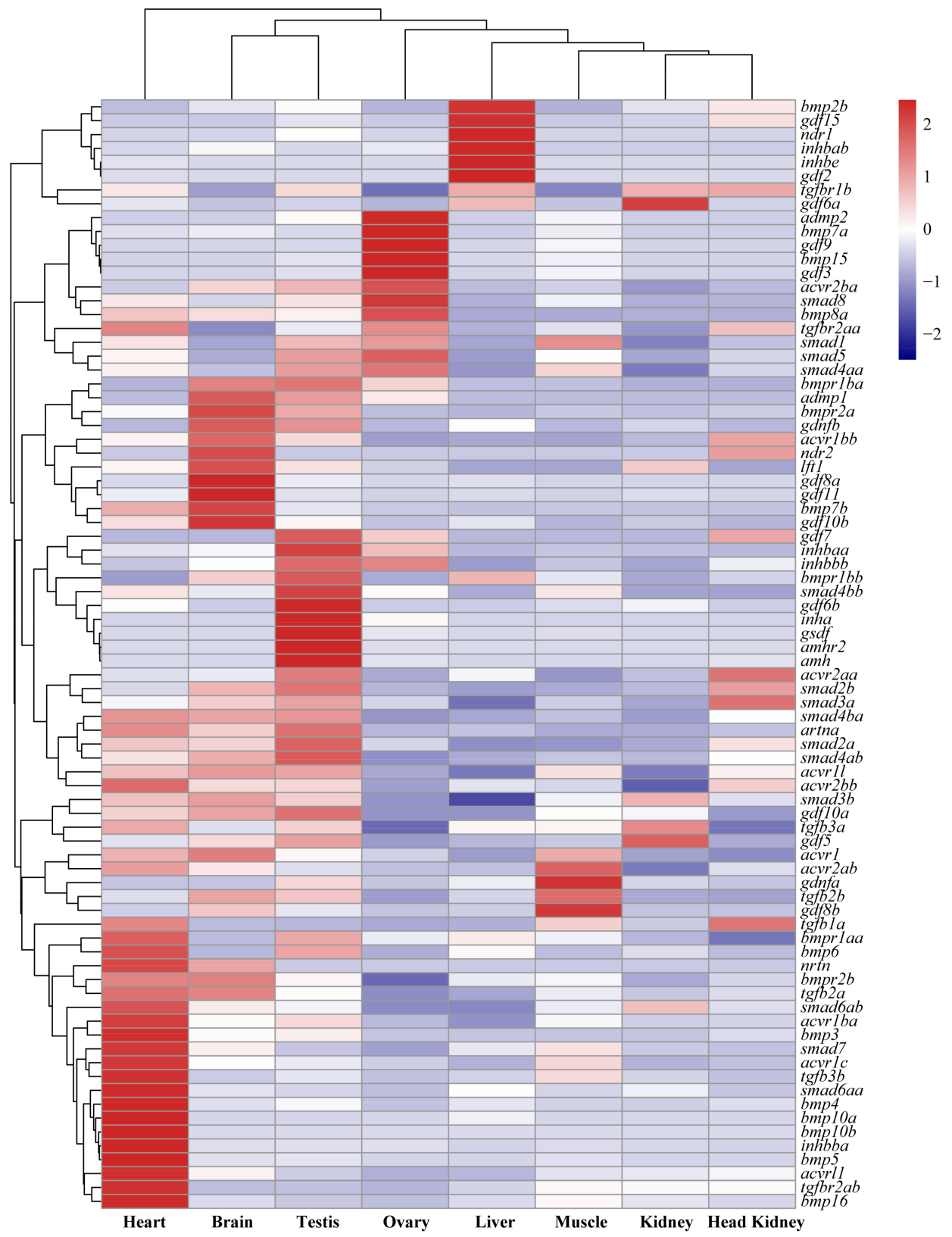

Figure 6. Tissue distribution (FPKM: fragments per kilobase of exon per million fragments mapped) of TGF- $\beta$ pathway members in eight tissues of tilapia based on transcriptome data. A heat map showing expression of TGF- $\beta$ pathway members in tilapia eight tissues, with red and blue indicating high and low expression, respectively. Each row represents a different gene, and each column represents an independent tissue sample. Hierarchical clustering of both genes and tissues (by correlation) organized the data set into similar expression patterns. The widespread complex expression patterns in all tissues were readily discernable. Most receptors and smads were expressed in multiple tissues while the ligands exhibited tissue-specific expression pattern especially in the heart and gonads. 


\begin{tabular}{|c|c|c|c|c|c|c|c|c|c|c|c|c|c|c|c|c|}
\hline & $5 \mathrm{~d} X X$ & $5 \mathrm{dXY}$ & $7 \mathrm{~d} X X$ & $7 \mathrm{~d} \mathrm{XY}$ & $20 \mathrm{~d} \mathrm{XX}$ & $20 \mathrm{dXY}$ & $30 \mathrm{~d} X X$ & 30d XY & $40 \mathrm{~d} X X$ & $40 \mathrm{~d} X Y$ & 90d XX & 90d XY & 180d XX & $180 \mathrm{~d} X Y$ & 300d XX & $300 \mathrm{~d} X Y$ \\
\hline admp 2 & 0.16 & 0.63 & 0.45 & 0.28 & 0.24 & 0.18 & 2.48 & 1.41 & 0.08 & 0.09 & 60.50 & 2.56 & 99.65 & 1.83 & 57.92 & 0.92 \\
\hline bmp $7 a$ & 0.00 & 0.34 & 1.09 & 0.58 & 0.43 & 0.52 & 2.39 & 3.28 & 1.90 & 1.12 & 92.52 & 1.14 & 119.32 & 1.05 & 55.53 & 0.17 \\
\hline$g d f 9$ & 0.00 & 0.00 & 0.09 & 0.05 & 0.15 & 0.41 & 5.49 & 4.50 & 2.52 & 0.09 & 428.97 & 4.98 & 345.91 & 3.22 & 161.36 & 0.44 \\
\hline bmp15 & 2.11 & 15.36 & 1.14 & 0.69 & 0.84 & 0.50 & 8.06 & 5.89 & 3.41 & 1.72 & 376.98 & 10.80 & 529.43 & 9.53 & 372.83 & 2.50 \\
\hline$g d f 3$ & 0.33 & 3.16 & 0.21 & 0.06 & 0.15 & 0.25 & 9.37 & 8.92 & 1.55 & 0.36 & 167.67 & 2.71 & 256.10 & 3.00 & 118.58 & 0.38 \\
\hline$a c v 2 b a$ & 0.12 & 0.37 & 1.68 & 3.21 & 2.63 & 1.92 & 1.49 & 2.74 & 2.94 & 1.72 & 28.61 & 3.44 & 70.27 & 4.15 & 26.42 & 2.30 \\
\hline smadl & 5.93 & 5.69 & 9.81 & 13.74 & 8.32 & 9.85 & 17.61 & 36.81 & 8.52 & 16.45 & 117.80 & 52.11 & 154.13 & 55.26 & 39.25 & 11.77 \\
\hline smad5 & 3.77 & 5.02 & 20.30 & 19.48 & 15.93 & 19.13 & 26.69 & 47.50 & 29.05 & 28.71 & 154.33 & 37.84 & 185.84 & 58.43 & 79.99 & 13.28 \\
\hline smad8 & 3.31 & 0.89 & 4.12 & 4.72 & 3.47 & 3.73 & 7.91 & 14.26 & 4.95 & 4.40 & 176.24 & 12.96 & 183.55 & 7.68 & 69.08 & 5.00 \\
\hline inha & 9.40 & 4.32 & 29.04 & 41.93 & 58.74 & 56.02 & 210.77 & 314.49 & 48.99 & 79.79 & 23.94 & 215.25 & 75.89 & 212.06 & 43.77 & 69.32 \\
\hline amh & 89.91 & 13.14 & 64.95 & 38.34 & 63.56 & 188.34 & 219.95 & 1213.80 & 101.65 & 723.27 & 13.46 & 456.40 & 13.53 & 270.53 & 9.93 & 30.04 \\
\hline$a m h r 2$ & 0.98 & 0.85 & 38.75 & 41.67 & 64.95 & 44.62 & 55.21 & 72.45 & 44.61 & 78.69 & 5.43 & 52.62 & 0.87 & 45.65 & 0.31 & 33.24 \\
\hline gsdf & 2.60 & 4.45 & 218.76 & 1361.14 & 245.77 & 2958.63 & \begin{tabular}{|l|}
420.35 \\
\end{tabular} & 7017.63 & 877.27 & 4596.46 & 59.83 & 846.12 & 43.68 & 344.63 & 26.15 & $\mid 141.04$ \\
\hline
\end{tabular}

Figure 7. The expression profiles (FPKM) of TGF- $\beta$ pathway members in the tilapia gonads. admp2, bmp7a, gdf9, bmp15, gdf3, acvr2ba, smad1, smad5 and smad8 were ovary-enriched genes, while inha, gsdf, amh and $a m h r 2$ were testis-enriched genes. Red and blue indicate high and low expression, respectively.
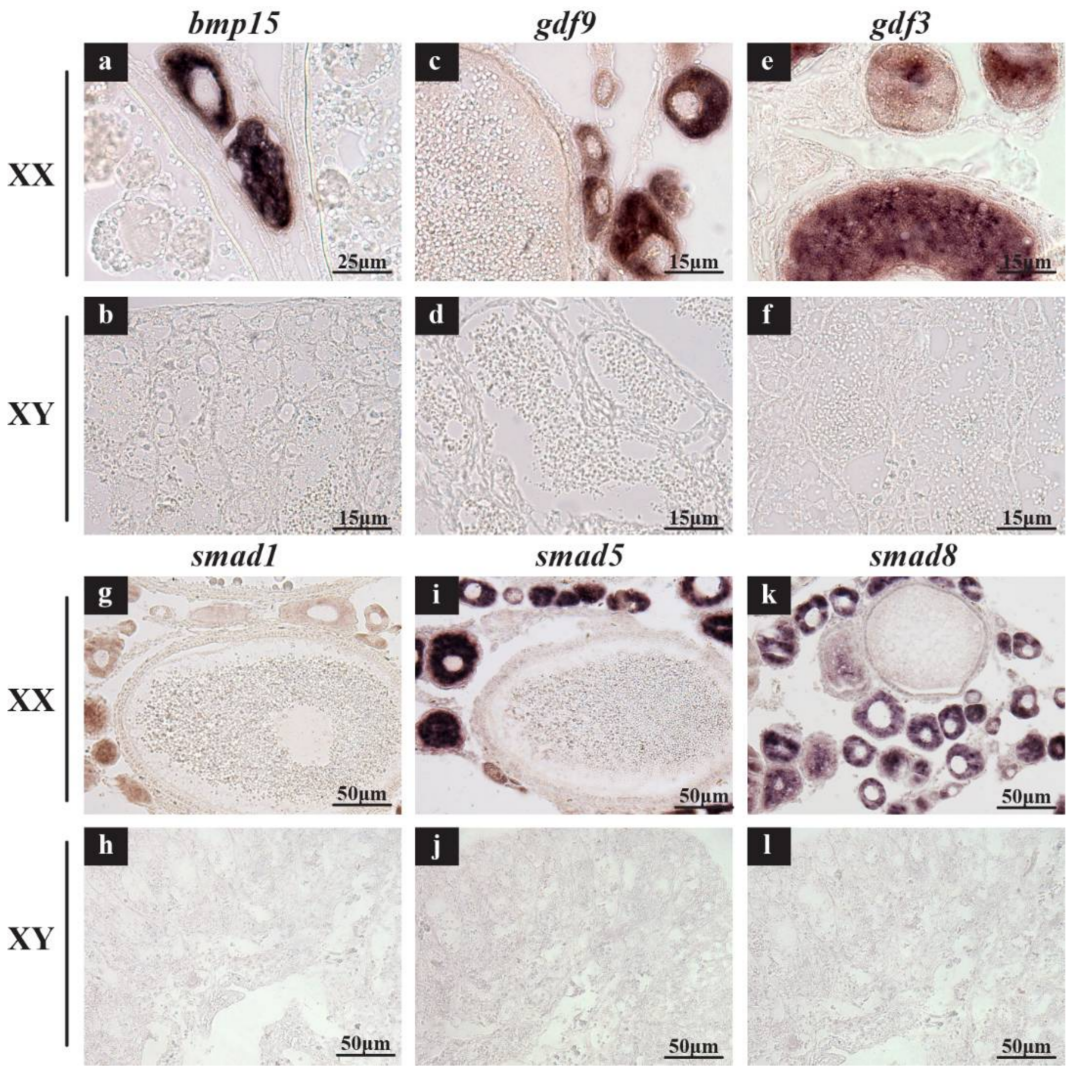

Figure 8. Cellular location of 6 TGF- $\beta$ pathway genes in tilapia gonads at 180 dah by ISH. Specific signals (brown) of $b m p 15, g d f 9, g d f 3$, smad1, smad5 and smad 8 were observed in the cytoplasm of oocytes in the ovary $(\mathbf{a}, \mathbf{c}, \mathbf{e}, \mathbf{g}, \mathbf{i}, \mathbf{k})$. In contrast, no signal of these genes was observed in any cells of the testis (b,d,f,h,j, $\mathbf{l})$. Scale bar: (a) $25 \mu \mathrm{m}$; (b-f) $15 \mu \mathrm{m} ;(\mathbf{g}-\mathbf{l}) 50 \mu \mathrm{m}$. 


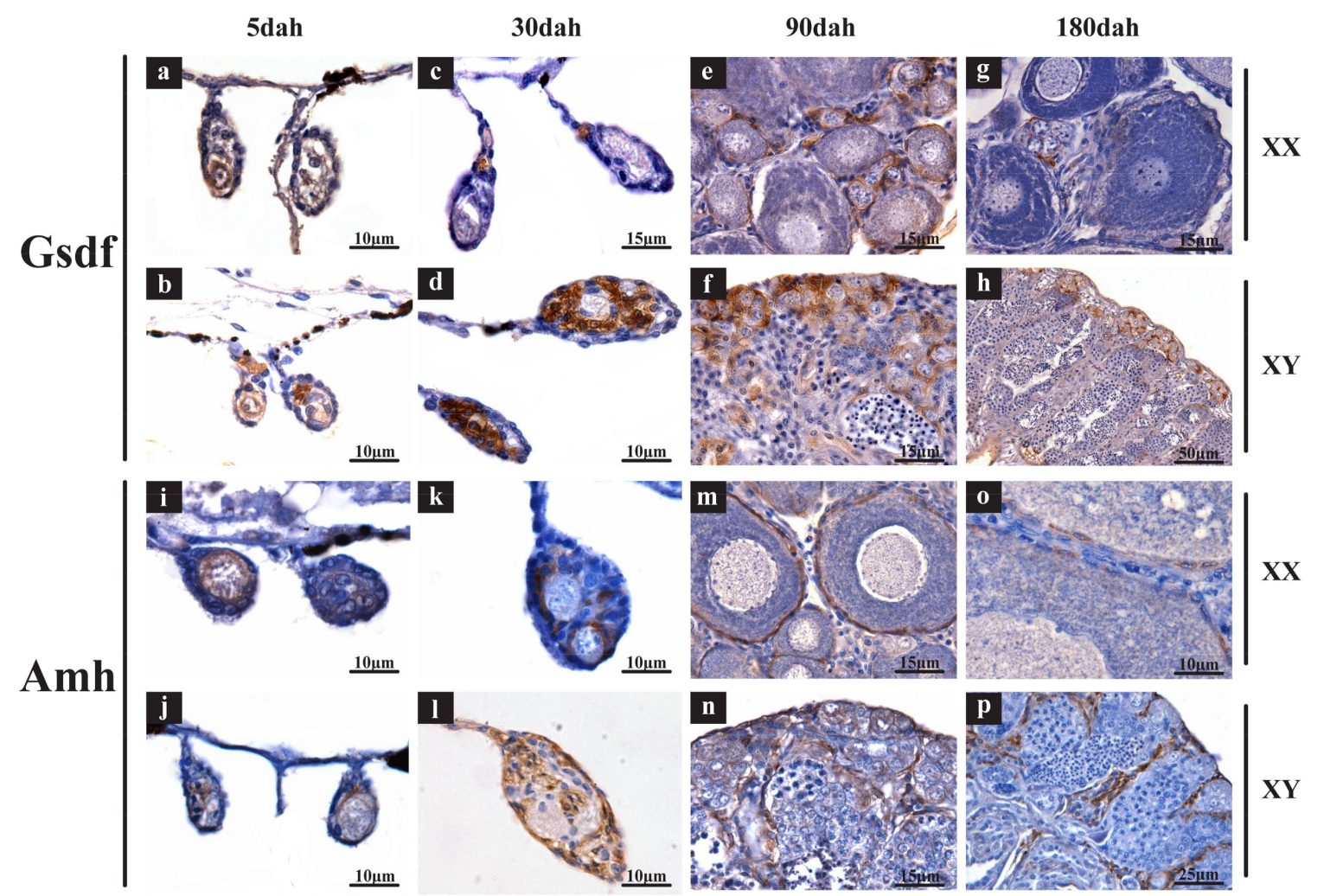

Figure 9. Cellular location of Gsdf and Amh in gonads by IHC. Gsdf-specific immunostaining was clearly observed in the somatic cells neighboring oogonia of XX gonads and Sertoli cells neighboring spermatogonia of the XY gonads at all stages $(\mathbf{a}-\mathbf{h})$. The Amh proteins were located in granule cells in ovary at all stages and somatic cells surrounding germ cells in the testis at 5 dah, and at later stages in myoid cells and Sertoli cells (i-p). Scale bar: (a,b,d,i-l,o) $10 \mu \mathrm{m} ;(\mathbf{c}, \mathbf{e}-\mathbf{g}, \mathbf{m}, \mathbf{n}) 15 \mu \mathrm{m}$; (p) $25 \mu \mathrm{m}$; (h) $50 \mu \mathrm{m}$.

\section{Discussion}

The growing number of sequenced species genomes provides more resources for understanding the evolution of gene families and developmental signaling pathways. Here, we focused on the TGF- $\beta$ pathway members, which play important roles in developmental specification, to retrace their origin and evolution, in particular gene duplications and losses. We also examined the expressions of all TGF- $\beta$ pathway members in the eight different tissues and their ontogenic expression in $X X / X Y$ gonads of tilapia.

\subsection{Evolution of the TGF- $\beta$ Signaling Pathway}

As has been proposed in the previous literature [21], our results supported that the appearance of the TGF- $\beta$ pathway was intrinsically linked to the emergence of metazoan. In this study, we examined TGF- $\beta$ pathway members in the genomes of 9 species of invertebrates and 15 species of chordates. We found that the diversity and total number of TGF- $\beta$ ligands, receptors and smads only varied slightly in all invertebrates and jawless vertebrates. In contrast, expansion of the pathway members, especially ligands, was observed in jawed vertebrates (gnathostomata) most likely due to $2 \mathrm{R}$ event. $3 R$ in teleosts and $4 \mathrm{R}$ in common carp were also observed although many TGF- $\beta$ pathway members were lost after duplication with only a single copy maintained. To be exact, expansion of TGF- $\beta$ ligands occurred at the early emergence of gnathostomes with retention rates approximately $70 \%$, while it occurred at 3R in teleosts with retention rates of only approximately 20\% (Figure 10a). Jawed vertebrates comprise more than $99 \%$ of living vertebrate species, including humans. Significant 
expansion of TGF- $\beta$ pathway members may set the stage for the generation of key vertebrate evolutionary novelties (like complex brains, heart, blood, bone, cartilage, musculature, and adipose tissue). Three TGF $\beta$ isoforms are important for heart development [50,51]. Divergence of TGFB1/2/3 in the jawed vertebrates (Figure 10a) has contributed to the formation of genuine heart. Significant expansion of BMPs/GDFs (BMP2-16, GDF1-15) (Figure 10a) is related not only to bone and cartilage development (such as BMP2, BMP4 and BMP7) [52], but also to muscle growth (GDF8) [53] and gonadal development and reproduction (BMP15, GDF9) [42,54]. In addition, a novel subfamily of TGF- $\beta$ ligands, GDNF, found in the jawed vertebrates (Figure 10a) is crucial for the development of vertebrate nervous system [55]. Additionally, the number of TGF- $\beta$ ligands greatly exceeded the number of type I and II receptors and smads in jawed vertebrates. This could be best explained by the fact that there are more constraints on intracellular relative to the extracellular components of the signaling pathway [56]. The TGF- $\beta$ ligands also radiated more than other extracellular protein families (Wnt and Notch families) of parallel importance in developmental specification. The evolutionary success of the TGF- $\beta$ ligands is in part a result of its large and complex prodomain. This enables complex regulation of biological function during signaling in extracellular environments that can be layered onto cell-surface and intracellular signaling in control of agonism and antagonism [57].

In previous studies, researchers found BMP16, a BMP2/4 relative, retained in the genomes of teleosts, was a product of 3R [58]. Subsequently, its presence was reported in a large number of Neopterygii species except in Chondrichthyes and Chondrostei [59]. In the present study, we successfully isolated $B M P 16$ in whale shark, further supported its $2 \mathrm{R}$ origin. Duplication of TGFB2 (TGFB2B), which was considered to be unique to teleosts in previous study [60], was also found in the elephant shark, coelacanth, and python. In line with synergy evolution, the copy of its type II receptor TGFBR2 (TGFBR2B) were not only detected in teleosts but also in elephant shark, coelacanth, spotted gar and tetrapods except mammals. Acvr1l, a novel type I receptor first identified in zebrafish [61], was found in the shark, coelacanth, spotted gar and other teleosts as well. Two SMAD4 genes were found in coelacanth, spotted gar and xenopus, and synteny analyses support their origin from genome duplication. Duplication of SMAD6 (SMAD6B) was also found in coelacanth, xenopus, python, and gecko. These phylogeny and synteny analyses results demonstrated that the duplication of the genes mentioned above all occurred from $2 R$. Orthologs of most TGF- $\beta$ genes in vertebrates can be identified in invertebrates even though they experienced several rounds of WGD during evolution. For instance, the origin of the type I receptor can be traced to ALK1/2 and ALK4/5/7 in invertebrates, sequentially ALK4/5/7 underwent duplication forming ALK3/6, then they underwent $2 R$ and 3R event. Only one type II receptor gene (ACVR2) was found in the early metazoan sponge and trichoplax indicating that it may be the ancestor-like molecule of type II receptors. Additionally, there were four kinds of smads, including SMAD1/5/8, SMAD2/3, SMAD4 and SMAD6/7 in invertebrates, then a whole SMAD family (SMAD1-8) generated after 2R (Figure 10b). However, some genes arose de novo at different stages of vertebrate evolution, such as $A M H$ and subfamily GDNF in gnathostomes and GSDF in actinopterygians (Figure 10a). 
a

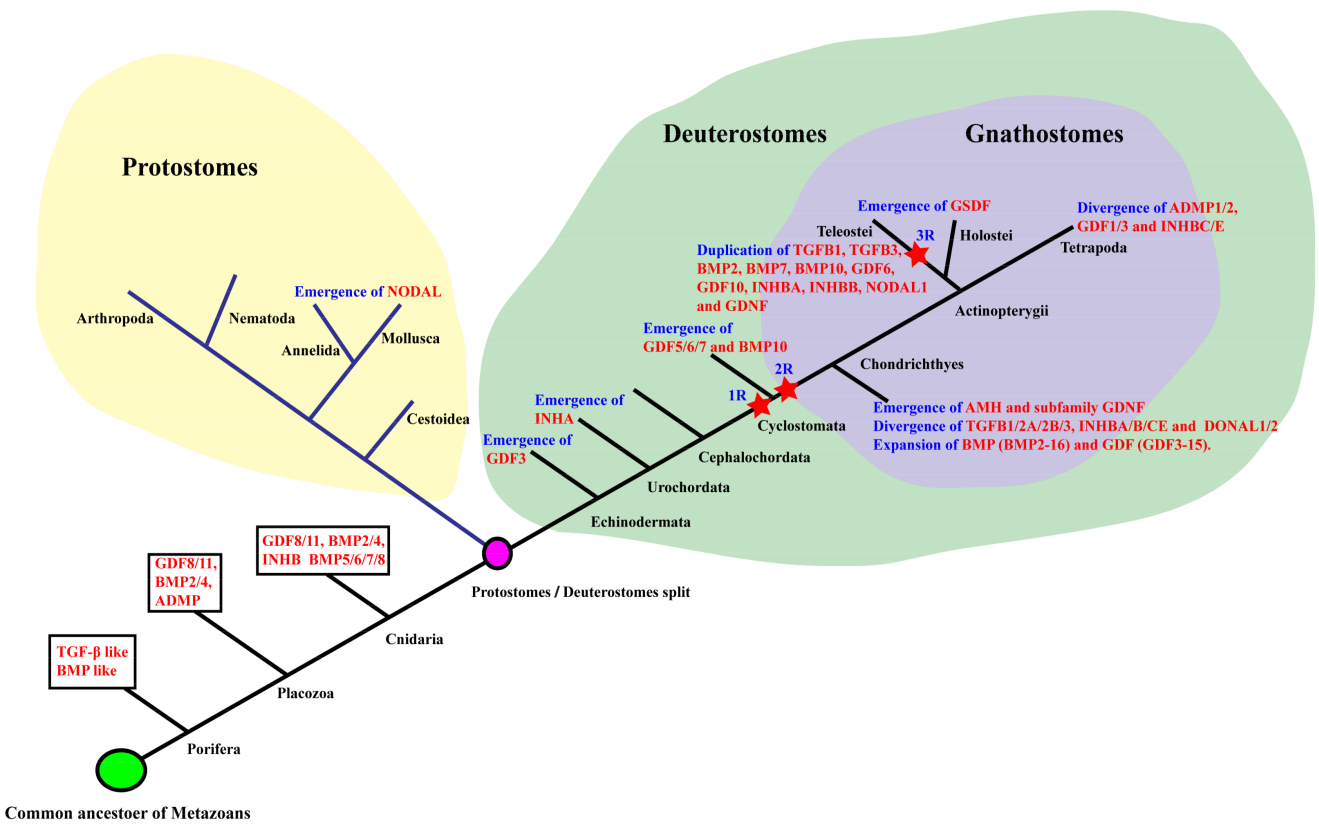

b

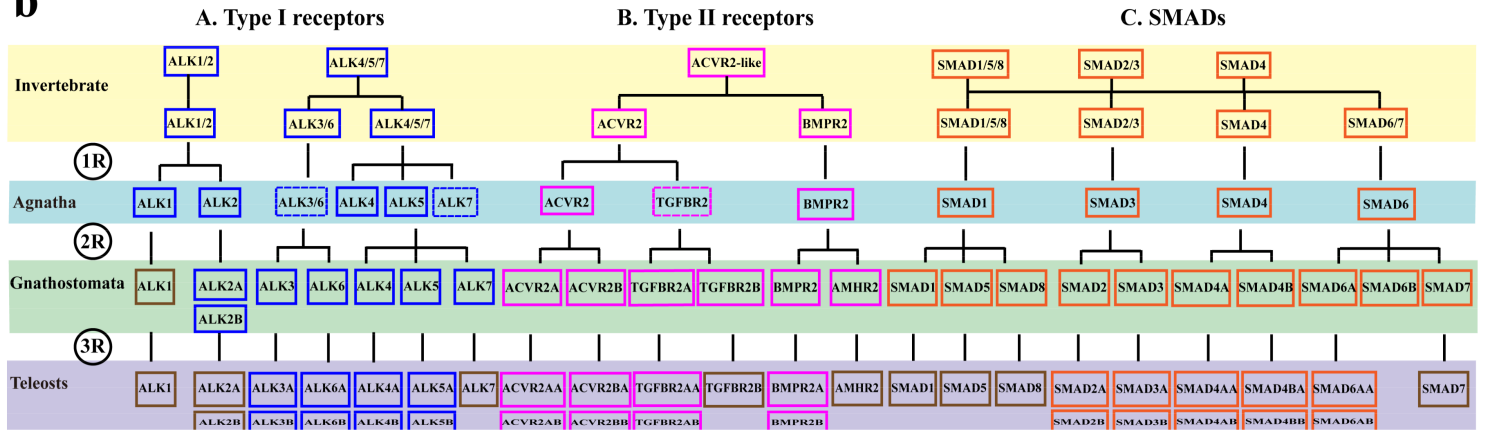

Figure 10. A schematic presentation of the evolution of TGF- $\beta$ pathway members. $1 R, 2 R$ and $3 R$ indicate the three rounds of WGD that occurred during vertebrate evolution. (a) Evolution of TGF- $\beta$ ligands. The evolutionary tree is constructed with references from the tree of life web project (Available online: http:/ / tolweb.org/tree/phylogeny.html). Branch lengths are not drawn to represent actual evolutionary distances. Protostomes, deuterostomes and gnathostomes were circled by yellow, green, and purple, respectively. Genes in the box indicate their presence in corresponding species. After split of protostome and deuterostome, changes (such as emergence, divergence, and duplication) of TGF- $\beta$ ligands were mapped onto corresponding branches. The early emergence of these genes including, NODAL in Mollusca and Annelida, INHA in Urochordata, GDF5/6/7 in Cyclostomata were obtained from previous studies [62-64]. (b) Evolution of TGF- $\beta$ type I receptors (A), type II receptors (B) and SMADs (C). The brown boxes indicate genes that with only one copy preserved after $2 \mathrm{R}$ or $3 R$. The dashed boxes indicate genes remain to be identified. The origins of the type I receptor can be traced to ALK1/2 and ALK4/5/7 in the vertebrate ancestor. Only one type II receptor ACVR2 was found in invertebrate. BMPR2 may be the paralog of $A C V R 2$ and the hypothetical origin of TGF- $\beta$ type II receptors was $A C V R 2$. The origin of the SMADs can be traced to SMAD1/5/8, SMAD2/3 and SMAD4 in early invertebrates. SMAD6/7 appeared later. Four SMADs, i.e., SMAD1, SMAD3, SMAD4 and SMAD6 appeared in agnatha. The whole SMAD family (SMAD1-8) were generated after 2R.

\subsection{Roles of TGF- $\beta$ Pathway Members in Heart, Liver, Especially in Gonads}

In the present study, transcriptomic analyses revealed that the majority of TGF- $\beta$ superfamily members expressed in at least one tissue in tilapia, indicating their essential roles in physiological processes and homeostasis. tgfb1a, tgfb3b, tgfbr2, bmp4, bmp10a, bmp10b, bmp16 and smad7 were 
preferentially expressed in heart as reported in previous studies [58,65-70]. We also found inhbba, bmp5 and bmp 6 were prominently expressed in heart. Gdf8b was found to be mainly expressed in the muscle. In mice, the physiological role of $G d f 8$, also known as myostatin, was to prevent overgrowth of muscle tissue [71]. Bmp9, expressed exclusively in the liver of tilapia, was reported to be required for liver cancer cell growth [72]. Our results also demonstrated that inhbe was prominently expressed in liver, which was consistent with the results in mouse and rat [73,74]. Overexpression of inhbe in the mouse liver can inhibit regenerative deoxyribonucleic acid synthesis of hepatic cells [75]. It was worth noting that most smads and receptors were expressed in multiple tissues while ligands exhibited a tissue-specific expression. Combining the diversity of ligands, it is possible that different ligands worked for different tissues, while the intracellular components were shared.

In tilapia gonads, bmp15, gdf9, gdf3, admp2, acvr2ba, bmp7a, smad1, smad5 and smad8 were identified as highly expressed genes in ovary, while $g s d f$, inha, amh and $a m h r 2$ were identified as highly expressed genes in testis. Generally, there are four key biological events occur during gonadal development of the tilapia: sex determination and differentiation at 5 dah, initiation of germ cell meiosis in ovary at 30 dah, initiation of germ cell meiosis in testis at $90 \mathrm{dah}$, and vitellogenesis in ovary and sperm maturation in testis at 180 dah [76]. Most XX-enriched genes were expressed in the germ cells of the ovary (bmp15, $g d f 9, g d f 3$ and smad1/5/8) and their expressions peaked at 180 dah indicating they are important for oogenesis. For instance, BMP15 and GDF9 are oocyte-specific growth factors which play important roles in granulosa cell development and fertility in animal models [77]. Deletion of Gdf9 results in arrest of folliculogenesis at the primary follicle stage and complete infertility in female mice [78] because the cuboidal granulosa cells fail to proliferate [54]. Admp2 and acvr $2 b a$ are also expressed highly in the ovary, indicating their possible participation in ovary development. Generally, $S M A D 1 / 5 / 8$ are regarded as the main responsible smads for downstream mediation of BMP signaling. Existing studies have been focused on the functional role of $S M A D 1 / 5 / 8$ as a whole, with little research exploring the role of a single smad. Their high expression in ovary from our study implied potential roles in ovary development. Targeted mutation in ovary can help elucidate the roles of these smads. Expressions of the XY-enriched genes started from 5 dah and peaked at 30 dah indicating their possible roles in male sex determination and differentiation. Some have suggested that in vertebrates, only a small number of genes, such as genes belonging to the Dmrt or Sox family, can be recruited to become the master genes of sex determination [38,79-81]. However, several novel sex-determining genes coding for TGF- $\beta$ pathway members were recently identified in teleosts. These included a tandem duplicate of amh on the Y chromosome (amhy) in tilapia (Oreochromis niloticus) [45], a Y-linked duplicate of the amh (amhy) in pejerrey (Odontesthes hatcheri) [44], $g s d f\left(g s d f^{Y}\right)$ in medaka (Oryzias luzonensis) [46] and $g d f 6\left(g d f \sigma^{Y}\right)$ in killifish (Nothobranchius furzeri) [47]. Even in Oryzias latipes and Oryzias dancena which use Dmy and $S o x 3^{Y}$ as sex-determining gene, respectively, mutation of $g s d f$ and $a m h r 2$ also induced sex reversal $[43,82]$. Overexpressing $g s d f$, a ray-finned fish-specific gene, in medaka and tilapia developing gonads converted XX individuals into functional males [38,39], while knockout of $g s d f$ in XY fish of these two species resulted in male to female sex reversal $[40,41]$ suggesting a conserved role of $g s d f$ in testicular development. Additionally, in zebrafish whose sex-determining gene has not yet been identified, female deficiency of bmp15 switched sex and became fertile males [42]. These data highlight the significant role for TGF- $\beta$ signaling pathway in teleost sex determination. Additionally, transcriptome data in tilapia showed that inha was exclusively expressed in the gonads, with higher expression in the testis than ovary. One possible role of inha in the ovary might be a mediator between GTH (gonadotropic hormone, including FSH and LH) and $g d f 9$ to control oogenesis as already proved in zebrafish [83]. However, its role in the testis need further investigations. AMH functions primarily through the type II receptor AMHR2 [84]. Previous reports suggested that AMH/AMHR2 signaling plays an important role in fish sex determination $[43,45,85]$. Interestingly enough, AMHR2 was not identified in Chimaeriformes (elephant shark, whale shark) and Cypriniformes, at least in Cyprinidae (zebrafish, common carp, grass carp, bluntnose black bream), even though they had the ligand $A M H$, which indicated that $A M H R 2$ probably first appeared in Osteichthyes and was lost secondarily in 
Cyprinidae after 2R. We speculated that another type II receptor, most likely BMPR2, might be recruited as $A M H$ receptor in these species. It is worth noting that zebrafish has different sex determination mechanism compared to the other teleosts which may be attributed to the absence of AMHR2.

In this study, the temporal and spatial expression profiles from transcriptome data were validated by examination of eight TGF- $\beta$ pathway genes, bmp15, $g d f 9, g d f 3$, smad1, smad5, smad8, gsdf and amh by qPCR, ISH and IHC. All displayed similar ontogeny expression patterns as those from transcriptome data. In addition, gsdf and amh were identified as XY-enriched genes in this study, which were consistent with the results reported previously in medaka and tilapia $[40,45]$. The tissue distribution of TGF- $\beta$ s and Inhibins in tilapia agreed well with that reported in mammals [86-88]. Furthermore, the expression profiles of TGF- $\beta$ family members based on the gonadal transcriptome data from our group [76] and from adult fish downloaded from NCBI [89] were quite similar. All these results provided useful data for further study of the function of this signaling pathway in the animal kingdom, especially in teleosts.

\section{Materials and Methods}

\subsection{Identification of TGF- $\beta$ Pathway Members in Representative Animal Species}

We examined the genomes of 24 representative animal species (sponges, trichoplax, jellyfish, tapeworm, nematode, leech, oyster, fruit fly, common urchin, vase tunicate, lancelet, lamprey, elephant shark, coelacanth, spotted gar, tilapia, medaka, fugu, zebrafish, common carp, western clawed frog, Burmese python, chicken and human) to identify TGF- $\beta$ pathway members in each species. The genomic sequences of all species are available at the NCBI and Ensembl database. All members were identified by tblastn $\left(E=2 \times 10^{-5}\right)$ against genome sequences, using zebrafish and human TGF- $\beta$ members as the query sequences.

\subsection{Phylogenetic Analyses and Genomic Distribution}

The amino acid sequences of TGF- $\beta$ pathway members were aligned by Clustal $X$ with default parameters using the multiple alignment software BioEdit (Carlsbad, USA) [90]. Phylogenetic trees were generated by the maximum likelihood (ML) method using the program MEGA 6.0 software (Tempe, USA) [91] with a bootstrap of 1000 replicates to assess the confidence in the phylogeny [92].

Genomic distribution of TGF- $\beta$ pathway members was performed using UCSC Blat search (Available online: http://genome.ucsc.edu/cgi-bin/hgBlat) [93]. Position and orientation of smad4 and its adjacent genes on chromosome were determined using Genomicus (Available online: http://www.genomicus.biologie.ens.fr/genomicus-89.01/cgi-bin/search.pl) [94].

\subsection{Expression Analyses of Tilapia TGF- $\beta$ Pathway Members in Adult Tissues and Gonads at Different Developmental Stages}

The transcriptomes of brain, heart, liver, ovary, testis, kidney, muscle and head kidney of adult tilapia were downloaded from the NCBI database (Accession codes: PRJNA78915 and SRR1916191) [4,89]. A normalized measure of FPKM (fragments per kilobase of exon per million fragments mapped) was used to normalize the expression profiles of TGF- $\beta$ pathway members. TGF- $\beta$ pathway members with a threshold of RPKM value $\geq 1.25$ in each tissue or the total FPKM $\geq 10$ in all eight tissues were used to determine a reasonable expression [95]. Bidirectional hierarchical clustering analyses were performed using the pheatmap package (Available online: https://cran.r-project.org/web/packages/pheatmap/index.html) in R language to cluster gene expression values and tissues $[96,97]$. Tissue distribution (FPKM) of TGF- $\beta$ pathway members in eight adult tissues of tilapia are listed in Table S3.

Eight pairs of $X X$ and $X Y$ gonadal transcriptomes from tilapia at eight developmental stages, 5, 7 , $20,30,40,90,180,300$ dah (days after hatching) were sequenced in our previous study [88]. TGF- $\beta$ pathway members with RPKM $<1.25$ in each sample or the total FPKM $<20$ in 16 transcriptomes from 
eight developmental stages were considered arbitrarily as background expression. Standards and identification of XX/XY-enriched genes of the TGF- $\beta$ pathway members were performed as described previously [95]. Two-tailed Student's t-test was used to compare the expression difference of TGF- $\beta$ pathway members between testis and ovary, and $p<0.05$ was considered statistically significant.

\subsection{Validation of Expression Profile of TGF- $\beta$ Pathway Members by qPCR and Cellular Location by ISH and IHC}

Ontogeny expression of $b m p 15$ and $g d f 9$ was examined by qPCR. Gonads were dissected from XX and XY tilapia at 5, 30, 90, 180 dah (about 2-200 gonads were collected at each time point depending on the gonad size). Three replicates were uesd for each stage. The mRNAs were extracted and reverse transcribed into cDNA according to the protocol described previously [98]. qPCR examination was carried out according to the manufacturer's protocol of The SYBR Green I Master Mix (TaKaRa, Dalian, China). Three genes ( $\beta$-actin, gapdh and eef1a1a) of tilapia were used as internal controls to normalize the expression of the two genes. The Data are presented as mean \pm SD. Statistical significance was defined by one-way analysis of variance (ANOVA) followed by post hoc test using the statistical package GraphPad Prism (GraphPad Software, Inc., La Jolla, USA), and $p<0.05$ was considered statistically significant.

Bmp15, gdf9, gdf3 and smad1/5/8 were XX-enriched genes from our transcriptome data. To ascertain which population of cells in gonads expressed these genes, ISH was performed using tilapia ovaries and testes at 180 dah. The fixation, embedding, sectioning of dissected gonads and ISH were performed as described previously [99]. Probes of sense and antisense digoxigenin (DIG)-labeled RNA strands were transcribed in vitro from linearized pGEM-T easy-bmp15/gdf9/gdf3/smad1/smad5/smad8 cDNA using a RNA labeling kit (Roche, Mannheim, Germany).

Gsdf and amh were XY-enriched genes from our transcriptome data. To locate the cellular expression pattern of the two genes in the developing gonads, IHC was performed using tilapia ovaries and testes at 5, 30, 90 and 180 dah. Gonads were collected and fixed in Bouin's solution overnight, and then dehydrated, embedded in paraffin and sectioned at $5 \mu \mathrm{m}$ thickness. Gsdf and Amh polyclonal antibodies for tilapia prepared by our group were used to examine their respective expression in tilapia gonads at 1:1000 and 1:500 dilution, respectively [41,45]. For the negative control, the primary antibody was replaced with normal rabbit serum. The sections were incubated with a second antibody (goat anti-rabbit IgG) conjugated with horseradish peroxidase (Bio-Rad, Hercules, CA, USA) at 1:2000. Immunoreactive signals were visualized using diaminobenzidine (Sigma, Burlington, MA, USA) as substrate. An Olympus BX51 light microscope (Olympus, Tokyo, Japan) was used to image the stained sections. Sequences of primers and probes used for qPCR and ISH, respectively, are listed in Table S4.

\section{Conclusions}

In summary, we have performed a detailed mining of TGF- $\beta$ signaling pathway across 24 animal species genomes. As shown in Figure 10, the TGF- $\beta$ signaling pathway appeared in the earliest-diverged multicellular animals. The total number of TGF- $\beta$ ligands, receptors and smads changed slightly in invertebrates and jawless vertebrates. In contrast, expansion of the pathway members, especially ligands, was observed in jawed vertebrates due to $2 \mathrm{R}$ event. Duplications of TGF- $\beta$ members were also observed from 3R in teleosts. Type II receptors may be originated from the ACVR2-like ancestor. Additionally, transcriptome data showed that most smads and receptors were expressed in multiple tissues while the ligands exhibited a tissue-specific expression especially in heart and gonads. Combining the diversity of ligands, it is possible that the intracellular components were shared by different ligands. Taken together, these results present a thorough overview of TGF- $\beta$ signaling pathway and provide a new perspective on the origin, evolution, and expression of this family in the animal kingdom, especially in vertebrates. 
Supplementary Materials: Supplementary materials can be found at http:/ / www.mdpi.com/1422-0067/19/4/1154/s1.

Acknowledgments: This work was supported by grants 31630082 and 31502147 from the National Natural Science Foundation of China; grant cstc2015jcyjB80001 from the Natural Science Foundation Project of Chongqing, Chongqing Science and Technology Commission.

Author Contributions: Deshou Wang, Shuqing Zheng and Juan Long together conceived and designed the experiments; Shuqing Zheng, Juan Long and Zhilong Liu analyzed the data, performed the experiments, interpreted the results, and drafted the manuscript; Wenjing Tao critiqued the manuscript for important intellectual content; Deshou Wang drafted and critically edited the manuscript. All authors read and approved the final manuscript.

Conflicts of Interest: The authors declare no conflict of interest.

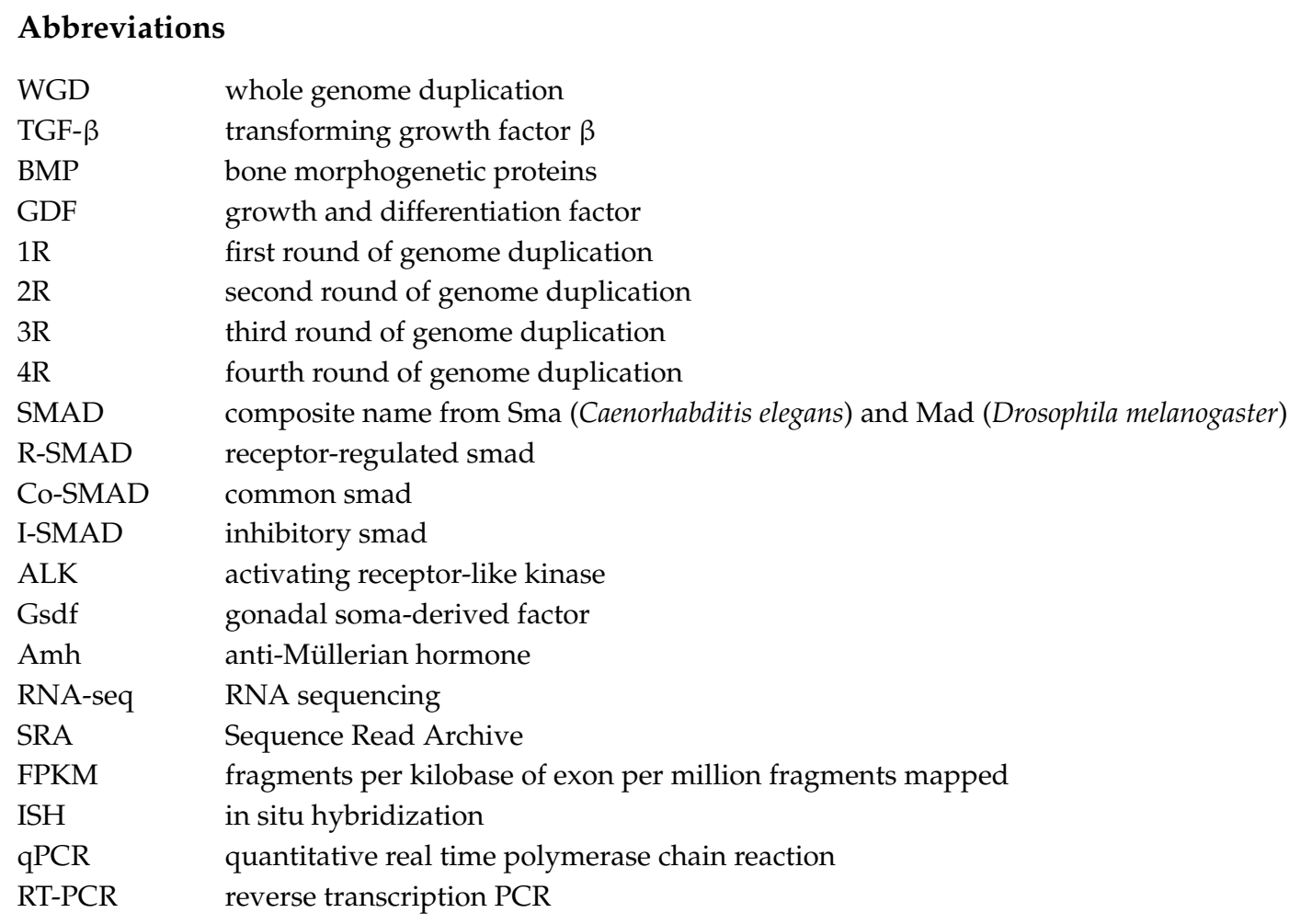

\section{References}

1. Ohno, S. Evolution by Gene Duplication; Springer: Berlin/Heidelberg, Germany, 1970.

2. Magadum, S.; Banerjee, U.; Murugan, P.; Gangapur, D.; Ravikesavan, R. Gene duplication as a major force in evolution. J. Genet. 2013, 92, 155-161. [CrossRef] [PubMed]

3. Huminiecki, L.; Heldin, C.H. 2R and remodeling of vertebrate signal transduction engine. BMC Biol. 2010, 8, 146. [CrossRef] [PubMed]

4. Cheng, Y.Y.; Tao, W.J.; Chen, J.L.; Sun, L.N.; Zhou, L.Y.; Song, Q.; Wang, D.S. Genome-wide identification, evolution and expression analysis of nuclear receptor superfamily in Nile tilapia, Oreochromis niloticus. Gene 2015, 569, 141-152. [CrossRef] [PubMed]

5. Hoegg, S.; Brinkmann, H.; Taylor, J.S.; Meyer, A. Phylogenetic timing of the fish-specific genome duplication correlates with the diversification of teleost fish. J. Mol. Evol. 2004, 59, 190-203. [CrossRef] [PubMed]

6. Escriva, H.; Manzon, L.; Youson, J.; Laudet, V. Analysis of lamprey and hagfish genes reveals a complex history of gene duplications during early vertebrate evolution. Mol. Biol. Evol. 2002, 19, 1440-1450. [CrossRef] [PubMed]

7. Kuraku, S.; Meyer, A.; Kuratani, S. Timing of genome duplications relative to the origin of the vertebrates: Did cyclostomes diverge before or after? Mol. Biol. Evol. 2009, 26, 47-59. [CrossRef] [PubMed]

8. Chiu, C.H.; Dewar, K.; Wagner, G.P.; Takahashi, K.; Ruddle, F.; Ledje, C.; Bartsch, P.; Scemama, J.L.; Stellwag, E.; Fried, C.; et al. Bichir HoxA cluster sequence reveals surprising trends in ray-finned fish genomic evolution. Genome Res. 2004, 14, 11-17. [CrossRef] [PubMed] 
9. Berthelot, C.; Brunet, F.; Chalopin, D.; Juanchich, A.; Bernard, M.; Noel, B.; Bento, P.; Da Silva, C.; Labadie, K.; Alberti, A.; et al. The rainbow trout genome provides novel insights into evolution after whole-genome duplication in vertebrates. Nat. Commun. 2014, 5, 3657. [CrossRef] [PubMed]

10. Xu, P.; Zhang, X.; Wang, X.; Li, J.; Liu, G.; Kuang, Y.; Xu, J.; Zheng, X.; Ren, L.; Wang, G.; et al. Genome sequence and genetic diversity of the common carp, Cyprinus carpio. Nat. Genet. 2014, 46, 1212-1219. [CrossRef] [PubMed]

11. Dehal, P.; Boore, J.L. Two rounds of whole genome duplication in the ancestral vertebrate. PLoS Biol. 2005, 3, e314. [CrossRef] [PubMed]

12. Ogino, Y.; Kuraku, S.; Ishibashi, H.; Miyakawa, H.; Sumiya, E.; Miyagawa, S.; Matsubara, H.; Yamada, G.; Baker, M.E.; Iguchi, T. Neofunctionalization of androgen receptor by gain-of-function mutations in teleost fish lineage. Mol. Biol. Evol. 2016, 33, 228-244. [CrossRef] [PubMed]

13. Rabier, C.E.; Ta, T.; Ane, C. Detecting and locating whole genome duplications on a phylogeny: A probabilistic approach. Mol. Biol. Evol. 2014, 31, 750-762. [CrossRef] [PubMed]

14. Newfeld, S.J.; Wisotzkey, R.G.; Kumar, S. Molecular evolution of a developmental pathway: Phylogenetic analyses of transforming growth factor-beta family ligands, receptors and Smad signal transducers. Genetics 1999, 152, 783-795. [PubMed]

15. Sawatari, E.; Shikina, S.; Takeuchi, T.; Yoshizaki, G. A novel transforming growth factor-beta superfamily member expressed in gonadal somatic cells enhances primordial germ cell and spermatogonial proliferation in rainbow trout (Oncorhynchus mykiss). Dev. Biol. 2007, 301, 266-275. [CrossRef] [PubMed]

16. Schlunegger, M.P.; Grutter, M.G. An unusual feature revealed by the crystal structure at 2.2 A resolution of human transforming growth factor-beta 2. Nature 1992, 358, 430-434. [CrossRef] [PubMed]

17. Morikawa, M.; Derynck, R.; Miyazono, K. TGF- $\beta$ and the TGF- $\beta$ family: Context-dependent roles in cell and tissue physiology. Cold Spring Harb. Perspect. Biol. 2016, 8, a021873. [CrossRef] [PubMed]

18. Feng, X.H.; Derynck, R. Specificity and versatility in TGF- $\beta$ signaling through Smads. Annu. Rev. Cell Dev. Biol. 2005, 21, 659-693. [CrossRef] [PubMed]

19. Hata, A.; Chen, Y.G. TGF- $\beta$ signaling from receptors to smads. Cold Spring Harb. Perspect. Biol. 2016, 8, a022061. [CrossRef] [PubMed]

20. Patterson, G.I.; Padgett, R.W. TGF beta-related pathways. Roles in Caenorhabditis elegans development. Trend. Genet. 2000, 16, 27-33. [CrossRef]

21. Pang, K.; Ryan, J.F.; Baxevanis, A.D.; Martindale, M.Q. Evolution of the TGF- $\beta$ signaling pathway and its potential role in the ctenophore, Mnemiopsis leidyi. PLoS ONE 2011, 6, e24152. [CrossRef] [PubMed]

22. Upadhyay, A.; Moss-Taylor, L.; Kim, M.J.; Ghosh, A.C.; O'Connor, M.B. TGF- $\beta$ family signaling in Drosophila. Cold Spring Harb. Perspect. Biol. 2017, 9, a022152. [CrossRef] [PubMed]

23. Savage-Dunn, C.; Padgett, R.W. The TGF- $\beta$ family in Caenorhabditis elegans. Cold Spring Harb. Perspect. Biol. 2017, 9, a022178. [CrossRef] [PubMed]

24. Schmierer, B.; Hill, C.S. TGF $\beta-S M A D$ signal transduction: Molecular specificity and functional flexibility. Nat. Rev. Mol. Cell Biol. 2007, 8, 970-982. [CrossRef] [PubMed]

25. Huminiecki, L.; Goldovsky, L.; Freilich, S.; Moustakas, A.; Ouzounis, C.; Heldin, C.H. Emergence, development and diversification of the TGF- $\beta$ signalling pathway within the animal kingdom. BMC Evol. Biol. 2009, 9, 28. [CrossRef] [PubMed]

26. Heldin, C.H.; Moustakas, A. Signaling receptors for TGF- $\beta$ family members. Cold Spring Harb. Perspect. Biol. 2016, 8, a022053. [CrossRef] [PubMed]

27. Du, X.; Liu, Y.; Liu, J.; Zhang, Q.; Wang, X. Evolution history of duplicated smad3 genes in teleost: Insights from Japanese flounder, Paralichthys olivaceus. PeerJ 2016, 4, e2500. [CrossRef] [PubMed]

28. Smith, J.J.; Kuraku, S.; Holt, C.; Sauka-Spengler, T.; Jiang, N.; Campbell, M.S.; Yandell, M.D.; Manousaki, T.; Meyer, A.; Bloom, O.E.; et al. Sequencing of the sea lamprey (Petromyzon marinus) genome provides insights into vertebrate evolution. Nat. Genet. 2013, 45, 415. [CrossRef] [PubMed]

29. Venkatesh, B.; Lee, A.P.; Ravi, V.; Maurya, A.K.; Lian, M.M.; Swann, J.B.; Ohta, Y.; Flajnik, M.F.; Sutoh, Y.; Kasahara, M.; et al. Elephant shark genome provides unique insights into gnathostome evolution. Nature 2014, 505, 174-179. [CrossRef] [PubMed]

30. Amemiya, C.T.; Alfoldi, J.; Lee, A.P.; Fan, S.; Philippe, H.; Maccallum, I.; Braasch, I.; Manousaki, T.; Schneider, I.; Rohner, N.; et al. The African coelacanth genome provides insights into tetrapod evolution. Nature 2013, 496, 311-316. [CrossRef] [PubMed] 
31. Braasch, I.; Gehrke, A.R.; Smith, J.J.; Kawasaki, K.; Manousaki, T.; Pasquier, J.; Amores, A.; Desvignes, T.; Batzel, P.; Catchen, J.; et al. The spotted gar genome illuminates vertebrate evolution and facilitates human-teleost comparisons. Nat. Genet. 2016, 48, 427-437. [CrossRef] [PubMed]

32. Massague, J.; Blain, S.W.; Lo, R.S. TGFbeta signaling in growth control, cancer, and heritable disorders. Cell 2000, 103, 295-309. [CrossRef]

33. Chang, H.; Brown, C.W.; Matzuk, M.M. Genetic analysis of the mammalian transforming growth factor-beta superfamily. Endocr. Rev. 2002, 23, 787-823. [CrossRef] [PubMed]

34. Ikushima, H.; Miyazono, K. TGF $\beta$ signalling: A complex web in cancer progression. Nat. Rev. Cancer. 2010, 10, 415-424. [CrossRef] [PubMed]

35. Matus, D.Q.; Pang, K.; Marlow, H.; Dunn, C.W.; Thomsen, G.H.; Martindale, M.Q. Molecular evidence for deep evolutionary roots of bilaterality in animal development. Proc. Natl. Acad. Sci. USA 2006, 103, 11195-11200. [CrossRef] [PubMed]

36. Zinski, J.; Tajer, B.; Mullins, M.C. TGF- $\beta$ family signaling in early vertebrate development. Cold Spring Harb. Perspect. Biol. 2017. [CrossRef] [PubMed]

37. Monsivais, D.; Matzuk, M.M.; Pangas, S.A. The TGF- $\beta$ family in the reproductive tract. Cold Spring Harb. Perspect. Biol. 2017, 9, a022251. [CrossRef] [PubMed]

38. Takehana, Y.; Matsuda, M.; Myosho, T.; Suster, M.L.; Kawakami, K.; Shin, I.T.; Kohara, Y.; Kuroki, Y.; Toyoda, A.; Fujiyama, A.; et al. Co-option of Sox3 as the male-determining factor on the $\mathrm{Y}$ chromosome in the fish Oryzias dancena. Nat. Commun. 2014, 5, 4157. [CrossRef] [PubMed]

39. Kaneko, H.; Ijiri, S.; Kobayashi, T.; Izumi, H.; Kuramochi, Y.; Wang, D.S.; Mizuno, S.; Nagahama, Y. Gonadal soma-derived factor $(g s d f)$, a TGF- $\beta$ superfamily gene, induces testis differentiation in the teleost fish Oreochromis niloticus. Mol. Cell. Endocrinol. 2015, 415, 87-99. [CrossRef] [PubMed]

40. Zhang, X.; Guan, G.; Li, M.; Zhu, F.; Liu, Q.; Naruse, K.; Herpin, A.; Nagahama, Y.; Li, J.; Hong, Y. Autosomal gsdf acts as a male sex initiator in the fish medaka. Sci. Rep. 2016, 6, 19738. [CrossRef] [PubMed]

41. Jiang, D.N.; Yang, H.H.; Li, M.H.; Shi, H.J.; Zhang, X.B.; Wang, D.S. gsdf is a downstream gene of dmrt1 that functions in the male sex determination pathway of the Nile tilapia. Mol. Reprod. Dev. 2016, 83, 497-508. [CrossRef] [PubMed]

42. Dranow, D.B.; Hu, K.; Bird, A.M.; Lawry, S.T.; Adams, M.T.; Sanchez, A.; Amatruda, J.F.; Draper, B.W. BMP15 is an oocyte-produced signal required for maintenance of the adult female sexual phenotype in zebrafish. PLoS Genet. 2016, 12, e1006323. [CrossRef] [PubMed]

43. Morinaga, C.; Saito, D.; Nakamura, S.; Sasaki, T.; Asakawa, S.; Shimizu, N.; Mitani, H.; Furutani-Seiki, M.; Tanaka, M.; Kondoh, H. The hotei mutation of medaka in the anti-Mullerian hormone receptor causes the dysregulation of germ cell and sexual development. Proc. Natl. Acad. Sci. USA 2007, 104, 9691-9696. [CrossRef] [PubMed]

44. Hattori, R.S.; Murai, Y.; Oura, M.; Masuda, S.; Majhi, S.K.; Sakamoto, T.; Fernandino, J.I.; Somoza, G.M.; Yokota, M.; Strussmann, C.A. A Y-linked anti-Mullerian hormone duplication takes over a critical role in sex determination. Proc. Natl. Acad. Sci. USA 2012, 109, 2955-2959. [CrossRef] [PubMed]

45. Li, M.; Sun, Y.; Zhao, J.; Shi, H.; Zeng, S.; Ye, K.; Jiang, D.; Zhou, L.; Sun, L.; Tao, W.; et al. A tandem duplicate of anti-Mullerian hormone with a missense SNP on the $Y$ chromosome is essential for male sex determination in Nile tilapia, Oreochromis niloticus. PLoS Genet. 2015, 11, e1005678. [CrossRef] [PubMed]

46. Myosho, T.; Otake, H.; Masuyama, H.; Matsuda, M.; Kuroki, Y.; Fujiyama, A.; Naruse, K.; Hamaguchi, S.; Sakaizumi, M. Tracing the emergence of a novel sex-determining gene in medaka, Oryzias luzonensis. Genetics 2012, 191, 163-170. [CrossRef] [PubMed]

47. Reichwald, K.; Petzold, A.; Koch, P.; Downie, B.R.; Hartmann, N.; Pietsch, S.; Baumgart, M.; Chalopin, D.; Felder, M.; Bens, M.; et al. Insights into sex chromosome evolution and aging from the genome of a short-lived fish. Cell 2015, 163, 1527-1538. [CrossRef] [PubMed]

48. Namwanje, M.; Brown, C.W. Activins and Inhibins: Roles in development, physiology, and disease. Cold Spring Harb. Perspect. Boil. 2016, 8, a021881. [CrossRef] [PubMed]

49. Katagiri, T.; Watabe, T. Bone morphogenetic proteins. Cold Spring Harb. Perspect. Biol. 2016, 8, a021899. [CrossRef] [PubMed]

50. Camenisch, T.D.; Molin, D.G.; Person, A.; Runyan, R.B.; Gittenberger-de Groot, A.C.; McDonald, J.A.; Klewer, S.E. Temporal and distinct TGF $\beta$ ligand requirements during mouse and avian endocardial cushion morphogenesis. Dev. Biol. 2002, 248, 170-181. [CrossRef] [PubMed] 
51. Boyer, A.S.; Ayerinskas, I.I.; Vincent, E.B.; McKinney, L.A.; Weeks, D.L.; Runyan, R.B. TGF $\beta 2$ and TGF $\beta 3$ have separate and sequential activities during epithelial-mesenchymal cell transformation in the embryonic heart. Dev. Biol. 1999, 208, 530-545. [CrossRef] [PubMed]

52. Bandyopadhyay, A.; Tsuji, K.; Cox, K.; Harfe, B.D.; Rosen, V.; Tabin, C.J. Genetic analysis of the roles of BMP2, BMP4, and BMP7 in limb patterning and skeletogenesis. PLoS Genet. 2006, 2, e216. [CrossRef] [PubMed]

53. Lee, S.J.; McPherron, A.C. Regulation of myostatin activity and muscle growth. Proc. Natl. Acad. Sci. USA 2001, 98, 9306-9311. [CrossRef] [PubMed]

54. Elvin, J.A.; Yan, C.; Wang, P.; Nishimori, K.; Matzuk, M.M. Molecular characterization of the follicle defects in the growth differentiation factor 9-deficient ovary. Mol. Endocrinol. 1999, 13, 1018-1034. [CrossRef] [PubMed]

55. Airaksinen, M.S.; Holm, L.; Hatinen, T. Evolution of the GDNF family ligands and receptors. Brain Behav. Evol. 2006, 68, 181-190. [CrossRef] [PubMed]

56. Herpin, A.; Lelong, C.; Favrel, P. Transforming growth factor- $\beta$-related proteins: An ancestral and widespread superfamily of cytokines in metazoans. Dev. Comp. Immunol. 2004, 28, 461-485. [CrossRef] [PubMed]

57. Hinck, A.P.; Mueller, T.D.; Springer, T.A. Structural biology and evolution of the TGF- $\beta$ family. Cold Spring Harb. Perspect. Biol. 2016, 8, a022103. [CrossRef] [PubMed]

58. Feiner, N.; Begemann, G.; Renz, A.J.; Meyer, A.; Kuraku, S. The origin of bmp16, a novel Bmp2/4 relative, retained in teleost fish genomes. BMC Evol. Biol. 2009, 9, 277. [CrossRef] [PubMed]

59. Marques, C.L.; Fernández, I.; Rosa, J.; Viegas, M.N.; Cancela, M.L.; Laizé, V. Spatiotemporal expression and retinoic acid regulation of bone morphogenetic proteins 2, 4 and 16 in Senegalese sole. J. Appl. Ichthyol. 2014, 30, 713-720. [CrossRef]

60. Funkenstein, B.; Olekh, E.; Jakowlew, S.B. Identification of a novel transforming growth factor- $\beta$ (TGF- $\beta 6$ ) gene in fish: Regulation in skeletal muscle by nutritional state. BMC Mol. Biol. 2010, 11, 37. [CrossRef] [PubMed]

61. Yelick, P.C.; Abduljabbar, T.S.; Stashenko, P. zALK-8, a novel type I serine/threonine kinase receptor, is expressed throughout early zebrafish development. Dev. Dyn. 1998, 211, 352-361. [CrossRef]

62. Grande, C.; Martin-Duran, J.M.; Kenny, N.J.; Truchado-Garcia, M.; Hejnol, A. Evolution, divergence and loss of the Nodal signalling pathway: New data and a synthesis across the Bilateria. Int. J. Dev. Biol. 2014, 58, 521-532. [CrossRef] [PubMed]

63. Zhu, J.; Braun, E.L.; Kohno, S.; Antenos, M.; Xu, E.Y.; Cook, R.W.; Lin, S.J.; Moore, B.C.; Guillette, L.J., Jr.; Jardetzky, T.S.; et al. Phylogenomic analyses reveal the evolutionary origin of the inhibin alpha-subunit, a unique TGF $\beta$ superfamily antagonist. PLoS ONE 2010, 5, e9457. [CrossRef] [PubMed]

64. Cerny, R.; Cattell, M.; Sauka-Spengler, T.; Bronner-Fraser, M.; Yu, F.; Medeiros, D.M. Evidence for the prepattern/cooption model of vertebrate jaw evolution. Proc. Natl. Acad. Sci. USA 2010, 107, 17262-17267. [CrossRef] [PubMed]

65. Wang, F.; Reece, E.A.; Yang, P. Oxidative stress is responsible for maternal diabetes-impaired transforming growth factor $\beta$ signaling in the developing mouse heart. Am. J. Obstet. Gynecol. 2015, 212, 650-e1. [CrossRef] [PubMed]

66. Wu, T.; Ling, Q.Y.; Zhong, C.; Wang, T.X.; Wang, L.L.; Wang, X.Y.; Su, Z.L.; Zong, G.J. Expression of BMP4 in myocardium and vascular tissue of obese mice. J. Inflamm. 2015, 12, 8. [CrossRef] [PubMed]

67. Neuhaus, H.; Rosen, V.; Thies, R.S. Heart specific expression of mouse BMP-10 a novel member of the TGF- $\beta$ superfamily. Mech. Dev. 1999, 80, 181-184. [CrossRef]

68. Chen, H.; Shi, S.; Acosta, L.; Li, W.; Lu, J.; Bao, S.; Chen, Z.; Yang, Z.; Schneider, M.D.; Chien, K.R.; et al. $\mathrm{BMP} 10$ is essential for maintaining cardiac growth during murine cardiogenesis. Development 2004, 131, 2219-2231. [CrossRef] [PubMed]

69. Langlois, D.; Hneino, M.; Bouazza, L.; Parlakian, A.; Sasaki, T.; Bricca, G.; Li, J.Y. Conditional inactivation of TGF- $\beta$ type II receptor in smooth muscle cells and epicardium causes lethal aortic and cardiac defects. Transgenic Res. 2010, 19, 1069-1082. [CrossRef] [PubMed]

70. Tang, S.; Snider, P.; Firulli, A.B.; Conway, S.J. Trigenic neural crest-restricted Smad7 over-expression results in congenital craniofacial and cardiovascular defects. Dev. Biol. 2010, 344, 233-247. [CrossRef] [PubMed]

71. McPherron, A.C.; Lawler, A.M.; Lee, S.J. Regulation of skeletal muscle mass in mice by a new TGF- $\beta$ superfamily member. Nature 1997, 387, 83-90. [CrossRef] [PubMed] 
72. Herrera, B.; Garcia-Alvaro, M.; Cruz, S.; Walsh, P.; Fernandez, M.; Roncero, C.; Fabregat, I.; Sanchez, A.; Inman, G.J. BMP9 is a proliferative and survival factor for human hepatocellular carcinoma cells. PLoS ONE 2013, 8, e69535. [CrossRef] [PubMed]

73. Fang, J.; Wang, S.Q.; Smiley, E.; Bonadio, J. Genes coding for mouse activin $\beta_{C}$ and $\beta_{E}$ are closely linked and exhibit a liver-specific expression pattern in adult tissues. Biochem. Biophys. Res. Commun. 1997, 231, 655-661. [CrossRef] [PubMed]

74. Vejda, S.; Cranfield, M.; Peter, B.; Mellor, S.L.; Groome, N.; Schulte-Hermann, R.; Rossmanith, W. Expression and dimerization of the rat activin subunits $\beta_{C}$ and $\beta_{E}$ : Evidence for the formation of novel activin dimers. J. Mol. Endocrinol. 2002, 28, 137-148. [CrossRef] [PubMed]

75. Chabicovsky, M.; Herkner, K.; Rossmanith, W. Overexpression of activin $\beta_{C}$ or activin $\beta_{E}$ in the mouse liver inhibits regenerative deoxyribonucleic acid synthesis of hepatic cells. Endocrinology 2003, 144, 3497-3504. [CrossRef] [PubMed]

76. Tao, W.; Yuan, J.; Zhou, L.; Sun, L.; Sun, Y.; Yang, S.; Li, M.; Zeng, S.; Huang, B.; Wang, D. Characterization of gonadal transcriptomes from Nile tilapia (Oreochromis niloticus) reveals differentially expressed genes. PLoS ONE 2013, 8, e63604. [CrossRef] [PubMed]

77. Yan, C.; Wang, P.; DeMayo, J.; DeMayo, F.J.; Elvin, J.A.; Carino, C.; Prasad, S.V.; Skinner, S.S.; Dunbar, B.S.; Dube, J.L.; et al. Synergistic roles of bone morphogenetic protein 15 and growth differentiation factor 9 in ovarian function. Mol. Endocrinol. 2001, 15, 854-866. [CrossRef] [PubMed]

78. Dong, J.; Albertini, D.F.; Nishimori, K.; Kumar, T.R.; Lu, N.; Matzuk, M.M. Growth differentiation factor-9 is required during early ovarian folliculogenesis. Nature 1996, 383, 531-535. [CrossRef] [PubMed]

79. Matsuda, M.; Nagahama, Y.; Shinomiya, A.; Sato, T.; Matsuda, C.; Kobayashi, T.; Morrey, C.E.; Shibata, N.; Asakawa, S.; Shimizu, N.; et al. DMY is a Y-specific DM-domain gene required for male development in the medaka fish. Nature 2002, 417, 559-563. [CrossRef] [PubMed]

80. Nanda, I.; Kondo, M.; Hornung, U.; Asakawa, S.; Winkler, C.; Shimizu, A.; Shan, Z.; Haaf, T.; Shimizu, N.; Shima, A.; et al. A duplicated copy of DMRT1 in the sex-determining region of the $\mathrm{Y}$ chromosome of the medaka, Oryzias latipes. Proc. Natl. Acad. Sci. USA 2002, 99, 11778-11783. [CrossRef] [PubMed]

81. Graves, J.A. How to evolve new vertebrate sex determining genes. Dev. Dyn. 2013, 242, 354-359. [CrossRef] [PubMed]

82. Imai, T.; Saino, K.; Matsuda, M. Mutation of Gonadal soma-derived factor induces medaka XY gonads to undergo ovarian development. Biochem. Biophys. Res. Commun. 2015, 467, 109-114. [CrossRef] [PubMed]

83. Poon, S.K.; So, W.K.; Yu, X.; Liu, L.; Ge, W. Characterization of inhibin alpha subunit (inha) in the zebrafish: Evidence for a potential feedback loop between the pituitary and ovary. Reproduction 2009, 138, 709-719. [CrossRef] [PubMed]

84. Josso, N.; di Clemente, N.; Gouedard, L. Anti-Mullerian hormone and its receptors. Mol. Cell. Endocrinol. 2001, 179, 25-32. [CrossRef]

85. Kamiya, T.; Kai, W.; Tasumi, S.; Oka, A.; Matsunaga, T.; Mizuno, N.; Fujita, M.; Suetake, H.; Suzuki, S.; Hosoya, S.; et al. A trans-species missense SNP in Amhr2 is associated with sex determination in the tiger pufferfish, Takifugu rubripes (fugu). PLoS Genet. 2012, 8, e1002798. [CrossRef] [PubMed]

86. Pangas, A.S.; Woodruff, K.T. Activin signal transduction pathways. Trends Endocr. Metab. 2000, 11, 309-314. [CrossRef]

87. Woodruff, T.K. Regulation of cellular and system function by activin. Biochem. Pharmacol. 1998, 55, 953-963. [CrossRef]

88. DePaolo, L.V. Inhibins, activins, and follistatins: The saga continues. Proc. Soc. Exp. Biol. Med. 1997, 214, 328-339. [CrossRef] [PubMed]

89. Brawand, D.; Wagner, C.E.; Li, Y.I.; Malinsky, M.; Keller, I.; Fan, S.; Simakov, O.; Ng, A.Y.; Lim, Z.W.; Bezault, E.; et al. The genomic substrate for adaptive radiation in African cichlid fish. Nature 2014, 513, 375-381. [CrossRef] [PubMed]

90. Hall, T.A. BioEdit: A user-friendly biological sequence alignment editor and analysis program for Windows 95/98/NT. Nucleic Acids Symp. Ser. 1999, 41, 95-98.

91. Tamura, K.; Stecher, G.; Peterson, D.; Filipski, A.; Kumar, S. MEGA6: Molecular evolutionary genetics analysis version 6.0. Mol. Biol. Evol. 2013, 30, 2725-2729. [CrossRef] [PubMed]

92. Felsenstein, J. Confidence Limits on Phylogenies: An approach using the bootstrap. Evol. Dev. 1985, 39, 783-791. [CrossRef] [PubMed] 
93. Tyner, C.; Barber, G.P.; Casper, J.; Clawson, H.; Diekhans, M.; Eisenhart, C.; Fischer, C.M.; Gibson, D.; Gonzalez, J.N.; Guruvadoo, L.; et al. The UCSC genome browser database: 2017 update. Nucleic Acids Res. 2017, 45, D626-D634. [PubMed]

94. Muffato, M.; Louis, A.; Poisnel, C.E.; Roest Crollius, H. Genomicus: A database and a browser to study gene synteny in modern and ancestral genomes. Bioinformatics 2010, 26, 1119-1121. [CrossRef] [PubMed]

95. Yuan, J.; Tao, W.; Cheng, Y.; Huang, B.; Wang, D. Genome-wide identification, phylogeny, and gonadal expression of fox genes in Nile tilapia, Oreochromis niloticus. Fish Physiol. Biochem. 2014, 40, 1239-1252. [CrossRef] [PubMed]

96. Szekely, G.J.; Rizzo, M.L. Hierarchical clustering via joint between-within distances: Extending ward's minimum variance method. J. Classif. 2005, 22, 151-183. [CrossRef]

97. Deza, M.M.; Deza, E. Encyclopedia of Distances; Springer: Berlin/Heidelberg, Germany, 2009; Volume 24, pp. 1-583.

98. Zhang, X.; Wang, H.; Li, M.; Cheng, Y.; Jiang, D.; Sun, L.; Tao, W.; Zhou, L.; Wang, Z.; Wang, D. Isolation of Doublesex- and Mab-3-related transcription factor 6 and its involvement in spermatogenesis in tilapia. Biol. Reprod. 2014, 91, 136. [CrossRef] [PubMed]

99. Kobayashi, T.; Kajiura-Kobayashi, H.; Nagahama, Y. Differential expression of vasa homologue gene in the germ cells during oogenesis and spermatogenesis in a teleost fish, tilapia, Oreochromis niloticus. Mech. Dev. 2000, 99, 139-142. [CrossRef]

(C) 2018 by the authors. Licensee MDPI, Basel, Switzerland. This article is an open access article distributed under the terms and conditions of the Creative Commons Attribution (CC BY) license (http:/ / creativecommons.org/licenses/by/4.0/). 